\title{
IOC Consensus Statement: Dietary Supplements and the High-Performance Athlete
}

\author{
Ronald J. Maughan \\ St Andrews University
}

D. Enette Larson-Meyer

University of Wyoming

Eric S. Rawson

Messiah College

Hans Geyer

German Sport University

\author{
Louise M. Burke \\ Australian Institute of Sport and \\ Mary MacKillop Institute \\ for Health Research
}

Peter Peeling

University of Western Australia and

Western Australian Institute of Sport

Neil P. Walsh
Bangor University

Romain Meeusen

Vrije Universiteit Brussel

\author{
Jiri Dvorak \\ Schulthess Clinic
}

\author{
Stuart M. Phillips \\ McMaster University
}

\author{
Lawrence L. Spriet \\ University of Guelph \\ $B M J$, London
}

Kevin Currell

English Institute of Sport, Loughborough

\author{
Margo Mountjoy \\ University of Guelph
}

\author{
Ina Garthe \\ Norwegian Olympic and Paralympic \\ Committee and Confederation of Sport \\ Luc van Loon \\ Mary MacKillop Institute \\ for Health Research and \\ Maastricht University Medical Centre \\ Mark Stuart \\ Vidya M. Ali and \\ Richard G.M. Budgett \\ International Olympic Committee
Yannis Pitsiladis, Torbjørn Soligard, Uğur Erdener, and Lars Engebretsen International Olympic Committee

\begin{abstract}
Nutrition usually makes a small but potentially valuable contribution to successful performance in elite athletes, and dietary supplements can make a minor contribution to this nutrition program. Nonetheless, supplement use is widespread at all levels of sport. Products described as supplements target different issues, including the management of micronutrient deficiencies, supply of convenient forms of energy and macronutrients, and provision of direct benefits to performance or indirect benefits such as

\footnotetext{
Note. This article is co-published with the British Journal of Sports Medicine (April 2018, Vol. 52, Issue 7; doi:10.1136/bjsports-2018-099027). Maughan and Shirreffs are with St Andrews University, St Andrews, UK. Burke is with the Australian Institute of Sport, Canberra, Australia. Burke and van Loon are with the Mary MacKillop Institute for Health Research, Melbourne, Australia. Dvorak is with Schulthess Clinic, Zurich, Switzerland. Larson-Meyer is with the University of Wyoming, Laramie, WY. Peeling is with The University of Western Australia, Crawley, Australia, and with the Western Australian Institute of Sport, Mt Claremont, Australia. Phillips is with McMaster University, Hamilton, Ontario, Canada. Rawson is with Messiah College, Mechanicsburg, PA. Walsh is with Bangor University, Bangor, United Kingdom. Garthe is with the Norwegian Olympic and Paralympic Committee and Confederation of Sport, Oslo, Norway. Geyer is with German Sport University, Cologne, Germany. Meeusen is with Vrije Universiteit Brussel, Brussels, Belgium. van Loon is also with Maastricht University Medical Centre, Maastricht, The Netherlands. Spriet is with the University of Guelph, Guelph, Ontario, Canada. Stuart is with BMJ, London, United Kingdom. Vernec is with the World Anti-Doping Agency, Montreal, Quebec, Canada. Currell is with the English Institute of Sport, Loughborough, United Kingdom. Ali, Budgett, Pitsiladis, Soligard, Erdener, and Engebretsen are with the International Olympic Committee, Lausanne, Switzerland. Ljungqvist is with the The Professor Arne Ljungqvist Anti-Doping Foundation, Stockholm, Sweden. Mountjoy is with the University of Guelph, Guelph, Ontario, Canada. Address author correspondence to Susan M. Shirreffs at s.shirreffs@st-andrews.ac.uk.
} 
supporting intense training regimens. The appropriate use of some supplements can offer benefits to the athlete, but others may be harmful to the athlete's health, performance, and/or livelihood and reputation if an anti-doping rule violation results. A complete nutritional assessment should be undertaken before decisions regarding supplement use are made. Supplements claiming to directly or indirectly enhance performance are typically the largest group of products marketed to athletes, but only a few (including caffeine, creatine, specific buffering agents and nitrate) have good evidence of benefits. However, responses are affected by the scenario of use and may vary widely between individuals because of factors that include genetics, the microbiome, and habitual diet. Supplements intended to enhance performance should be thoroughly trialed in training or simulated competition before implementation in competition. Inadvertent ingestion of substances prohibited under the anti-doping codes that govern elite sport is a known risk of taking some supplements. Protection of the athlete's health and awareness of the potential for harm must be paramount, and expert professional opinion and assistance is strongly advised before embarking on supplement use.

Keywords: banned substance, ergogenic aid, performance, sport nutrition

Dietary supplements are used by athletes at all levels of sport, reflecting the prevalence of their use in the wider society. About half of the adult US population uses some form of dietary supplements (Bailey et al., 2011) and, though there are regional, cultural, and economic differences, a similar prevalence is likely in many other countries. Athletes describe a range of different reasons for their supplement choices (Fennell, 2004), and products that fit the description of "supplement" can target various roles within the athlete's performance plan. These include the maintenance of good health by contributing to the required intake of specific nutrients, the management of micronutrient deficiencies, and the provision of energy and macronutrient needs that might be difficult to achieve through food intake alone. Other specific uses of supplements reported by athletes include direct performance enhancement or the indirect benefits that arise from the provision of support for hard training, the manipulation of physique, the alleviation of musculoskeletal pain, rapid recovery from injury, and enhancement of mood.

Some sporting bodies now support the pragmatic use of supplements that have passed a risk-vs.-benefit analysis of being effective, safe, and permitted for use, while also being appropriate to the athlete's age and maturation in their sport. This review summarizes the issues faced by high-performance athletes and their support team (coach, trainer, nutritionist, physician) when considering the use of supplements, with the goal of providing information to assist them to make informed decisions.

\section{What is a Supplement?}

There is no single definition, either legal or within nutritional science, of what constitutes a dietary supplement. The US Congress, for example, in framing the 1994 Dietary Supplements Health and Education Act (DSHEA), described a dietary supplement as: ". . . a product, other than tobacco, which is used in conjunction with a healthy diet and contains one or more of the following dietary ingredients: a vitamin, mineral, herb or other botanical, an amino acid, a dietary substance for use by man to supplement the diet by increasing the total daily intake, or a concentrate, metabolite, constituent, extract, or combinations of these ingredients" (Office of Dietary Supplements, National Institutes of Health, 1994).

This definition is unsatisfactory, as it depends on whether or not a "healthy diet" is consumed. For the purposes of this overview, we define a dietary supplement as: A food, food component, nutrient, or nonfood compound that is purposefully ingested in addition to the habitually-consumed diet with the aim of achieving a specific health and/or performance benefit.
Furthermore, we recognize that dietary supplements come in many forms, including:

(a) Functional foods: foods enriched with additional nutrients or components outside their typical nutrient composition (e.g., mineral- and vitamin-fortified, as well as nutrient-enriched foods)

(b) Formulated foods and sports foods: products providing energy and nutrients in a more convenient form than normal foods for general nutrition support (e.g., liquid meal replacements) or for targeted use around exercise (e.g., sports drinks, gels, bars)

(c) Single nutrients and other components of foods or herbal products provided in isolated or concentrated forms

(d) Multi-ingredient products containing various combinations of those products described above that target similar outcomes

\section{Prevalence of, and Rationale for, Use by Athletes}

With such widespread use of supplements in the general population and with the specific focus of athletes on achieving peak performance, it is not surprising that a high prevalence of supplement use is reported in most surveys of athletes (Maughan et al., 2007). Comparisons between surveys are confounded by numerous factors. These include differences in the definition of what constitutes a dietary supplement; ability to capture irregular use; inappropriate sample selection; and the use of nonvalidated and nonstandardized survey instruments (Garthe \& Maughan, 2018). Nevertheless, surveys generally suggest that supplement use:

(a) Varies across different sports and activities

(b) Increases with level of training/performance

(c) Increases with age

(d) Is higher in men than in women

(e) Is strongly influenced by perceived cultural norms (both sporting and nonsporting)

Although athletes often consume supplements to take advantage of intended/claimed effects or benefits, a range of motives underpins supplement use (Garthe \& Maughan, 2018). For example, athletes use supplements:

(a) To correct or prevent nutrient deficiencies that may impair health or performance 
(b) For convenient provision of energy and nutrients around an exercise session

(c) To achieve a specific and direct performance benefit in competition

(d) To gain a performance improvement indirectly accrued from outcomes such as allowing more effective training (i.e., higher intensity, greater volume), better recovery from training sessions, optimizing mass and body composition, or reducing risks of injury and illness

(e) For financial gain (sponsorship) or because products are provided free of charge

(f) As a "just in case" insurance policy

(g) Because they know or believe that other athletes/competitors are using the supplement(s)

Some supplements may be used for multiple functions. Zinc, for example, may be taken with the aim of promoting wound healing and tissue repair (Prasad, 2014) or reducing the severity and duration of the symptoms of an upper respiratory tract infection (Solomons, 1998). Carbohydrate supplements are used to enhance performance in many events via the provision of fuel substrate (Stellingwerff \& Cox, 2014), to support the immune system (Peake et al., 2017), or to improve bioavailability of other supplements (e.g., creatine; Steenge et al., 2000). Similarly, creatine supplementation may directly enhance performance in strength and power events, and can assist in training harder, gaining lean body mass, or maintaining lean mass during periods of immobilization after injury (Branch, 2003; Gualano et al., 2012; Heaton et al., 2017). Decisions on supplement use therefore need to consider both the context of use and the specific protocol employed.

\section{Assessing the Evidence Base for Supplement Use}

Supplements target a range of scenarios of use, so different approaches are needed to assess their effectiveness. Supplements aimed at correcting nutrient deficiencies need to be judged on their ability to prevent or treat suboptimal nutrient status, with the benefit accruing from the removal of the associated impairment of health, training capacity, or performance. The effectiveness of sports foods might be hard to isolate when they are used within the general diet to meet everyday energy needs and nutrient targets. However, benefits may be more easily detected when they are specifically consumed before, during, or after an event or training session to provide nutrients that are limiting for performance (e.g., to provide fuel for the muscle or brain) or to defend homeostasis (e.g., by replacing water and salt losses). Performance-enhancing supplements which are claimed to achieve direct or indirect benefits pose a greater challenge in terms of a sound evidence base. With only a few exceptions, there is a scarcity of research, and many of the available studies are not of sufficient quality to warrant their application to elite athletes.

Substantiating the claims made about performance supplements and sports foods is difficult (Burke \& Peeling, 2018). To various audiences, "proof" comes in different forms. Figure 1 provides a proposed hierarchical model of the relative strength of the evidence provided by different information sources. However, most of the information around supplement efficacy in sport comes from models with the lowest rigor: anecdotes/observations from athletes and scientific or mechanistic hypotheses that explain how a supplement might target a critical/limiting factor in performance, but with little to no evidence. Systematic reviews and

\section{Hierarchy of Scientific Evidence}

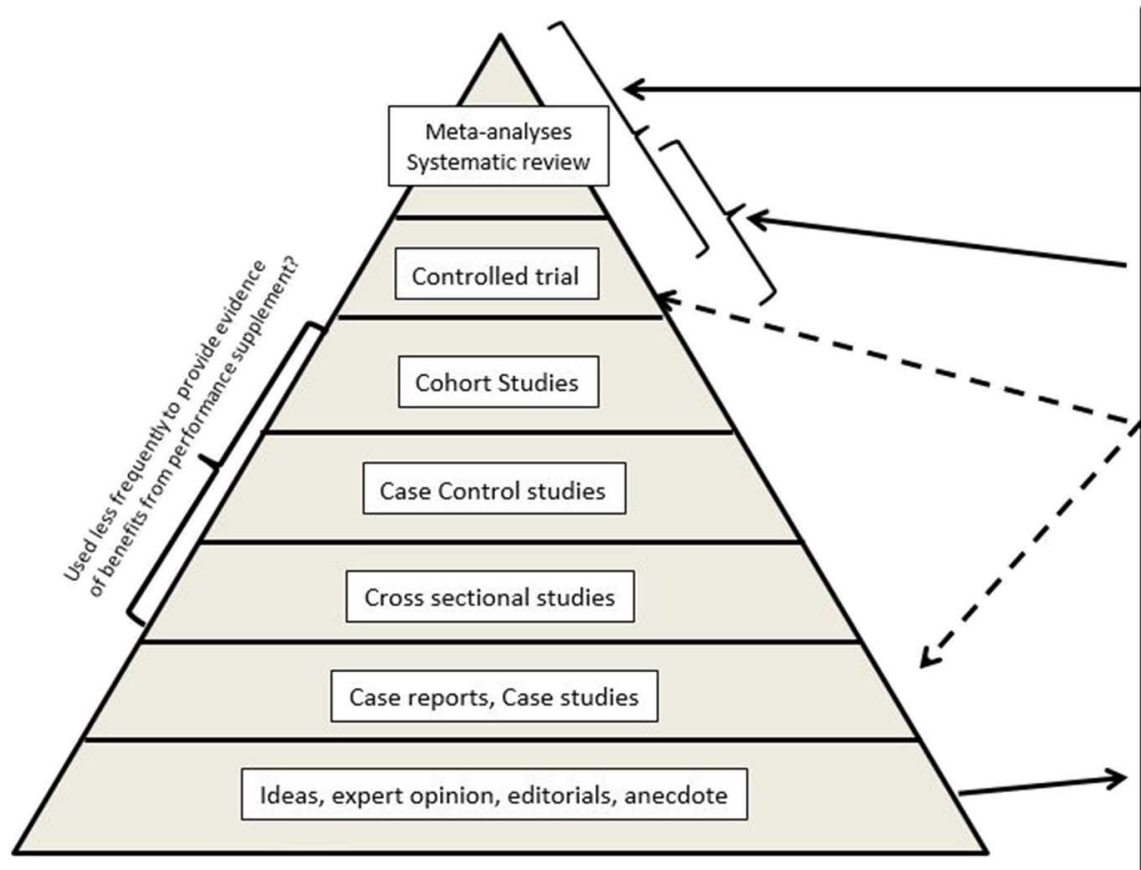

\section{Evidence matrix for performance supplements}

Figure 1 - Hierarchy of evidence used to establish good practice. Adapted from Burke and Peeling (2018). 
meta-analyses, which synthesize the outputs of many studies to yield a conclusive statement of efficacy in a broad sense, are at the top of the evidence hierarchy. While these summaries help to provide information about the general use of performance supplements, scientific trials that are properly controlled and wellconducted provide the basis for these reviews, as well as an opportunity to address more specific questions about supplement applications. Thus, meta-analyses are a reflection only of the quality and quantity of the studies that are available for review, and may also be influenced by the inclusion and exclusion criteria applied to the available data.

The gold standard for investigating the effects of supplements on sports performance is the prospective, randomized, controlled scientific trial, in which subjects are randomly allocated to receive either an experimental or placebo treatment (ideally in a double-blind manner) or crossed over to receive both treatments in counterbalanced order, under standardized conditions. Practical issues may cause some variations to ideal design, but sports scientists are encouraged, if they wish their results to be applicable to athletes in competition, to ensure that their studies include:

(a) An adequate sample size and appropriate participant characteristics (e.g., event, training status, caliber) to allow the results to have statistical power and to be applicable to highperformance athletes

(b) Mimicking, as far as possible, the conditions (e.g., environment, nutrition preparation, event strategies) that exist in real-life competition

(c) Standardization, to the extent that is possible, of variables that might influence the results (e.g., pretrial exercise and diet, environmental conditions, external encouragement or distraction). It is recognized that this conflicts to some extent with (b) above, and will limit the situations in which the results can be applied.

(d) Use of a protocol of supplement use (e.g., specific product, dose, and timing of intake) that is likely to optimize any effects

(e) An independent verification of the contents of the supplement under investigation to ensure that the product is truly unadulterated, both to ensure the integrity of the study and to avoid inadvertent doping positives if the subjects are athletes

(f) Verification that the supplement was taken and induced a biological response (e.g., via muscle, blood, urine, or saliva sampling)

(g) A performance protocol that is valid and sufficiently reliable to detect small but potentially meaningful changes/differences in performance outcomes.

(h) Interpretation of results in light of the limitations of the study design and the change that would be meaningful to reallife sport

Given the specificity of the information that is required by some athletes and their support staff to assess the effectiveness of a supplement (e.g., related to a targeted event and its conditions, the specific individual, the combination with other performance strategies), it is unreasonable to expect that definitive evidence will always be available. Issues that are particularly underresearched and should be considered of high priority include measurement of performance in the field or under "real-life" conditions, investigation of the combined use of a number of supplements, and the repeated use of supplements as might occur in multi-day competition or when heats and finals occur close together. Scenarios that fall outside the scope of the available literature or practical research design may need to be interrogated by individual or small group case studies. Recommended methodologies for these studies include repeated baseline performances before the introduction of the supplement, or an alternating series of presentation and absence of the supplement (Burke \& Peeling, 2018).

For the purposes of this overview, we rely primarily on studies of healthy adults that are relevant to athletes. We recognize that data from studies of elite athletes are almost entirely absent. We also recognize that mechanistic studies on animal and cell culture models are useful in identifying mechanisms, but a mechanism is not necessary to demonstrate an effect that may be meaningful to an athlete. What we think today to be the mechanism by which enhancement of performance or health occurs might be proved wrong by later studies. It must also be recognized that an individual's habitual diet can affect gene expression and their microbiota, and these, in turn, can affect response to supplementation. While the variation in the genome between individuals is less than $0.01 \%$, the variation in microbiota is significant (80-90\%), and emerging data suggests that both these factors could affect athletic performance (Clark \& Mach, 2017; Ribeiro et al., 2013). The following sections present an overview of the use of supplements to address different roles in sports nutrition, first by identifying the principles of use and then by examining some of the specific products that have a good or emerging evidence base to support this situationspecific use by athletes.

\section{Supplements Used to Prevent or Treat Nutrient Deficiencies}

Many micronutrients play an important role in the regulation of processes that underpin sports performance, ranging from energy production to the manufacture of new cells and proteins. A frank deficiency of one or more of these nutrients may lead to a measurable impairment of sports performance, either directly or by reducing the athlete's ability to train effectively (e.g., iron deficiency anemia) or to stay free from illness or injury (e.g., impact of vitamin D deficiency on bone health). Athletes are not immune to the inadequate eating practices or the increased nutrient loss/requirements found in some members of the general population and may even be at greater risk of deficiencies because of increased nutrient turnover or increased losses. A further challenge is the occurrence of subclinical deficiencies that may be both hard to assess (i.e., they lack a clear metric or universal threshold of what is "adequate") as well as subject to debate about whether there is an "optimal" level for performance that differs from the usual classification systems of nutrient status (deficiency/ subclinical, deficiency/normal). When suboptimal nutritional status is diagnosed, the use of a nutrient supplement to reverse or prevent further deficiencies can contribute to the overall treatment plan.

Nutritional assessment of an athlete involves systematic protocols that obtain, verify, and interpret evidence of nutrition-related problems, as well as their causes and significance. A complete assessment should ideally include a detailed medical and nutritional history, diet evaluation, anthropometry and body composition analysis, and biochemical testing (Larson-Meyer et al., 2018). Unlike the ad hoc use of nutrient supplements taken by 
athletes as an insurance policy, this nutritional assessment should ensure that the athlete:

(a) Can address the factors that led to the nutrient deficiency, including ensuring that the athlete's nutrition plan is adequate in energy, macronutrients, and micronutrients

(b) Would benefit from an acute or chronic period of supplementation to correct and/or prevent a nutrient deficiency and can understand the appropriate supplementation protocol

(c) Is not at risk for health issues associated with supplement use, including interactions with prescription or over-the-counter medications

(d) Has a baseline assessment against which future measures to assess progress can be compared

Nutrients that often need to be supplemented under these circumstances include iron, calcium, and vitamin D (Table 1). Iodine (for those living in areas with low levels of iodine in foods or not using iodized salt), folate (for women who might become pregnant), and vitamin B12 (for those following a vegan or near-vegan diet) supplementation may be warranted in these population groups, but these considerations do not apply specifically to athletes.

\section{Supplements (Sports Foods) Used to Provide a Practical Form of Energy and Nutrients}

Sports nutrition guidelines provide clear recommendations for targeted intake of energy and nutrients in a variety of contexts. In some situations, it is impractical for an athlete to consume "everyday" or normal foods to meet their nutrition goals due to issues around preparation or storage, ease of consuming the foods due to training schedules, gut comfort, or the challenge of meeting nutrient targets within the available energy budget. In these cases, sports foods can provide a convenient, albeit usually more expensive, alternative option for meeting these nutrient goals. Table 2 provides an overview of products that fit this description and their more common evidence-based uses.

\section{Table 1 Examples of Micronutrients Often Requiring Supplementation in Athletes*}

\begin{tabular}{|c|c|c|c|}
\hline Micronutrient & Overview & $\begin{array}{l}\text { Diagnosis and Outcomes of } \\
\text { Insufficiency }\end{array}$ & $\begin{array}{l}\text { Protocols and Outcomes of } \\
\text { Supplementation }\end{array}$ \\
\hline Vitamin D & $\begin{array}{l}\text { Important in regulation of gene tran- } \\
\text { scription in most tissues so insufficiency/ } \\
\text { deficiency affects many body systems } \\
\text { (Hossein-nezhad et al., 2013); many } \\
\text { athletes are at risk of insufficiency at } \\
\text { various times throughout the year } \\
\text { (Larson-Meyer \& Willis, 2010) }\end{array}$ & $\begin{array}{l}\text { No consensus over the serum } \\
\text { 25-hydroxyvitamin D concentration (the } \\
\text { marker of vitamin D status) that defines } \\
\text { deficiency, insufficiency, sufficiency, } \\
\text { and a tolerable UL; the need to } \\
\text { supplement depends on UVB exposure } \\
\text { and skin type }\end{array}$ & $\begin{array}{l}\text { Supplementation of between } 800 \mathrm{IU} \\
\text { and 1,000-2,000 IU/day is recom- } \\
\text { mended to maintain status for the gen- } \\
\text { eral population. Supplementation } \\
\text { guidelines are not yet established in } \\
\text { athletes. Short-term, high-dose supple- } \\
\text { mentation, which includes } 50,000 \text { IU/ } \\
\text { week for } 8-16 \text { weeks or } 10,000 \text { IU/day } \\
\text { for several weeks, may be appropriate } \\
\text { for restoring status in deficient athletes. } \\
\text { Careful monitoring is necessary to } \\
\text { avoid toxicity (Heaney, 2008). }\end{array}$ \\
\hline Iron & $\begin{array}{l}\text { Suboptimal iron status may result from } \\
\text { limited iron intake, poor bioavailability } \\
\text { and/or inadequate energy intake, or } \\
\text { excess iron need due to rapid growth, } \\
\text { high-altitude training, menstrual blood } \\
\text { loss, foot-strike hemolysis, or excess } \\
\text { losses in sweat, urine, or feces (Thomas } \\
\text { et al., 2016) }\end{array}$ & $\begin{array}{l}\text { Several measures performed } \\
\text { simultaneously provide the best } \\
\text { assessment and determine the stage of } \\
\text { deficiency; recommended measures: } \\
\text { serum ferritin, transferrin saturation, } \\
\text { serum iron, transferrin receptor, zinc } \\
\text { protoporphyrin, hemoglobin, } \\
\text { hematocrit, mean corpuscular volume } \\
\text { (Gibson, 2005) }\end{array}$ & $\begin{array}{l}\text { Athletes who do not maintain adequate } \\
\text { iron status may need supplemental } \\
\text { iron at doses greater than their RDA } \\
\text { (i.e., }>18 \mathrm{mg} / \text { day for women and } \\
>8 \mathrm{mg} / \text { day for men). Athletes with iron } \\
\text { deficiency require clinical follow-up } \\
\text { which may include supplementation } \\
\text { with larger doses of oral iron supple- } \\
\text { mentation along with improved dietary } \\
\text { iron intake (Thomas et al., 2016). } \\
\text { Numerous oral iron preparations are } \\
\text { available and most are equally effective } \\
\text { as long as they are taken (Schrier } \& \\
\text { Auerbach, } 2017 \text { ). High-dose iron } \\
\text { supplements, however, should be not } \\
\text { taken unless iron deficiency is present. }\end{array}$ \\
\hline Calcium & $\begin{array}{l}\text { Avoidance of dairy products and other } \\
\text { calcium-rich foods, restricted energy } \\
\text { intake, and/or disordered eating in- } \\
\text { creases risk of suboptimal calcium status } \\
\text { (Thomas et al., 2016) }\end{array}$ & $\begin{array}{l}\text { No appropriate indicator of calcium } \\
\text { status; bone mineral density scan may be } \\
\text { indicative of chronic low calcium intake } \\
\text { but other factors including suboptimal } \\
\text { vitamin D status and disordered eating } \\
\text { are also important }\end{array}$ & $\begin{array}{l}\text { Calcium intakes of } 1,500 \mathrm{mg} / \mathrm{day} \text { and } \\
1,500 \text { to } 2,000 \mathrm{IU} \text { vitamin } \mathrm{D} \text { are } \\
\text { recommended to optimize bone health } \\
\text { in athletes with low energy availability } \\
\text { or menstrual dysfunction (Thomas } \\
\text { et al., 2016). }\end{array}$ \\
\hline
\end{tabular}

Abbreviations: RDA = recommended dietary allowance; $\mathrm{UL}=$ upper limit; $\mathrm{UVB}=$ ultraviolet $\mathrm{B}$

* See Larson-Meyer et al. (2018) for additional information.

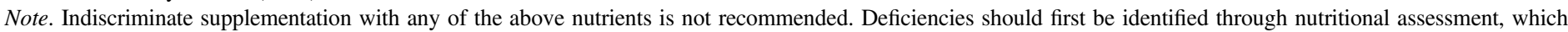
includes dietary intake and the appropriate blood or urinary marker, if available (Larson-Meyer et al., 2018). 
Table 2 Summary of Common Sports Foods and Functional Foods Used by Athletes

\begin{tabular}{llll}
\hline Sports Food & Form & Typical Composition & Common Sports-Related Use \\
\hline Sports drink & Powder or ready to drink liquid & $\begin{array}{l}5-8 \% \mathrm{CHO}, 10-35 \mathrm{mmol} / \mathrm{L} \text { sodium, } \\
3-5 \mathrm{mmol} / \mathrm{L} \text { potassium }\end{array}$ & $\begin{array}{l}\text { Simultaneous delivery of fluid }+\mathrm{CHO} \\
\text { during exercise; postexercise } \\
\text { rehydration and refueling }\end{array}$ \\
Energy drink & $\begin{array}{l}\text { Ready to drink liquid or } \\
\text { concentrated shot }\end{array}$ & $\begin{array}{l}\text { Carbohydrate, especially in typical ready } \\
\text { to drink varieties, caffeine } \\
\text { Pote: May contain taurine, B vitamins, } \\
\text { and other ingredients with variable }\end{array}$ & $\begin{array}{l}\text { carbohydrate and caffeine intake during } \\
\text { exere }\end{array}$
\end{tabular}

Sports gel or sports

confectionery

Electrolyte replacement supplements

Protein supplement

Liquid meal supplement

Powder (mix with water or milk) or ready-to-drink liquid

Powder (mix with water or milk) or ready-to-drink liquid; proteinrich bar, usually low in $\mathrm{CHO}$

Confectionery: Jelly-type confectionary (generally in pouch of $\sim 40-50 \mathrm{~g}$ )

Powder sachets or tablets and other ingredients supporting evidence and some level of concern

$\sim 25$ g CHO per sachet; $~ 5$ g CHO per confectionery piece (some contain caffeine or electrolytes)

50-60 mmol/L sodium, 10-20 $\mathrm{mmol} / \mathrm{L}$ potassium, typically low $\mathrm{CHO}$ (2-4 g/100 mL)

Provides $20-50$ g protein in a single serve from high-quality types of animal (whey, casein, milk, egg) or vegetable (e.g., soy) origin

Note: May contain other ingredients, some of which are not evidence based and may increase the risk of contamination

$1-1.5 \mathrm{kcal} / \mathrm{mL}: 15-20 \%$ protein and 50-70\% CHO; low to moderate fat; vitamins/minerals: $500-1000 \mathrm{~mL}$ supplies RDI/RDAs

40-50 g CHO, 5-10 g protein; usually low in fat and fiber; vitamins/minerals: $50-100 \%$ of RDA/RDIs

Note: May contain other ingredients, some of which are not evidence-based and may increase the risk of contamination

Protein-enhanced food Milk, yogurt, ice cream, cereal bars, and other food forms
Increased protein content from normal food variety achieved by adding protein sources or filtration of water from product; typically allows normal portion to provide $\sim 20 \mathrm{~g}$ protein to meet sports nutrition target
Carbohydrate intake during exercise

Rapid rehydration following dehydration undertaken for weight-making; replacement of large sodium losses during ultra-endurance activities; rapid postexercise rehydration following moderate to large fluid and sodium deficits

Postexercise recovery following key training sessions or events where adaptation requiring protein synthesis is desired; achievement of increase in lean mass during growth or response to resistance training; portable nutrition for busy schedule or travel

Supplement high-energy diet (especially during heavy training/competition or weight gain); low-bulk meal replacement (especially preevent meal); postexercise recovery $(\mathrm{CHO}$ and protein); portable nutrition for busy schedule or travel

CHO source during exercise; postexercise recovery (provides $\mathrm{CHO}$, protein, and micronutrients); portable nutrition for busy schedule or travel

Value added food able to achieve protein target for postexercise use or to improve protein content of other meals and snacks in athlete's diet

Abbreviations: $\mathrm{CHO}=$ carbohydrate $\mathrm{RDA}=$ recommended dietary allowance; $\mathrm{RDI}=$ reference daily intake .

\section{Supplements That Directly Improve Sports Performance}

A few performance-enhancing supplements might, at the present time, be considered to have an adequate level of support to suggest that marginal performance gains may be possible. These supplements include: caffeine, creatine (in the form of creatine monohydrate), nitrate, sodium bicarbonate, and possibly also $\beta$-alanine. The mechanisms of action, typical dose, potential performance benefits, and known side-effects of each of these supplements are summarized in Table 3. Performance-enhancing supplements should be considered only where a strong evidencebase supports their use as safe, legal, and effective, and, ideally, after adequacy of sports nutrition dietary practices is ensured. Whenever possible, supplements should be trialed thoroughly by the athlete in training that mimics the competition milieu as closely as possible before committing to use in a competition setting. Athletes should do a careful risk analysis to see if the marginal gains would outweigh the risk of inadvertent doping due to contamination. 


\section{Table 3 Supplements With Good to Strong Evidence of Achieving Benefits to Performance When Used in Specific Scenarios (see Peeling et al., 2018 for further details)}

\begin{tabular}{|c|c|}
\hline affeine & \\
\hline Overview & $\begin{array}{l}\text { Caffeine is a stimulant that possesses well-established benefits for athletic performance across endurance-based situations, } \\
\text { short-term, supramaximal, and/or repeated sprint tasks. }\end{array}$ \\
\hline Mechanism & $\begin{array}{l}\text { Adenosine receptor antagonism; increased endorphin release; improved neuromuscular function; improved vigilance and } \\
\text { alertness; reduce perception of exertion during exercise (Burke, 2008; Spriet, 2014) }\end{array}$ \\
\hline Protocol of use & $\begin{array}{l}3-6 \mathrm{mg} / \mathrm{kg} \text { of } \mathrm{BM} \text {, in the form of anhydrous caffeine (i.e., pill or powder form), consumed } \sim 60 \text { min prior to exercise (Gani } \\
\text { et al., 2009). Lower caffeine doses ( }<3 \mathrm{mg} / \mathrm{kg} \mathrm{BM}, \sim 200 \mathrm{mg}) \text {, provided both before and during exercise; consumed with a } \mathrm{CH} \\
\text { source (Spriet, 2014). }\end{array}$ \\
\hline Performance impact & $\begin{array}{l}\text { Improved endurance capacity such as exercise time to fatigue (French et al., 1991), and endurance-based TT activities of varying } \\
\text { duration (5-150 min), across numerous exercise modalities (i.e., cycling, running, rowing, and others; Ganio et al., 2009). Low- } \\
\text { doses of caffeine (100-300 mg) consumed during endurance exercise (after } 15-80 \mathrm{~min} \text { of activity) may enhance cycling TT } \\
\text { performance by 3-7\% (Paton et al., 2015; Talanian \& Spriet, 2016). During short-term, supramaximal, and repeated sprint tasks, } \\
3-6 \mathrm{mg} / \mathrm{kg} \text { BM of caffeine taken 50-60 min before exercise results in performance gains of }>3 \% \text { for task completion time, mean } \\
\text { power output, and peak power output during anaerobic activities of } 1-2 \text { min in duration (Wiles et al., 2006), and of 1-8\% for total } \\
\text { work output and repeat sprint performances during intermittent team game activity (Schneiker et al., 2006; Wellington et al., 2017). }\end{array}$ \\
\hline $\begin{array}{l}\text { Further considerations } \\
\text { and potential side effects }\end{array}$ & $\begin{array}{l}\text { Larger caffeine doses ( } \geq 9 \mathrm{mg} / \mathrm{kg} \mathrm{BM} \text { ) do not appear to increase the performance benefit (Bruce et al., 2000), and are more likel) } \\
\text { to increase the risk of negative side effects, including nausea, anxiety, insomnia, and restlessness (Burke, 2008). Lower caffein } \\
\text { doses, variations in the timing of intake before and/or during exercise, and the need for (or lack thereof) a caffeine withdrawa } \\
\text { period should be trialed in training prior to competition use. Caffeine consumption during activity should be considered } \\
\text { concurrent with CHO intake for improved efficacy (Talanian \& Spriet, 2016). Caffeine is a diuretic, promoting increased urin } \\
\text { flow, but this effect is small at the doses that have been shown to enhance performance (Maughan \& Griffin } 2003 \text { ) }\end{array}$ \\
\hline
\end{tabular}

\section{Creatine}

Overview

Creatine loading can acutely enhance the performance of sports involving repeated high-intensity exercise (e.g., team sports), as well as the chronic outcomes of training programs based on these characteristics (e.g., resistance or interval training), leading to greater gains in lean mass and muscular strength and power (Rawson \& Persky, 2007; Volek \& Rawson, 2004).

Mechanism Supplementation increases muscle creatine stores, augmenting the rate of $\mathrm{PCr}$ resynthesis, thereby enhancing short-term, highintensity exercise capacity (Buford et al., 2007) and the ability to perform repeated bouts of high-intensity effort.

Protocol of use Loading-phase: 20 g/day (divided into 4 equal daily doses), for 5-7 days (Lanhers et al., 2017) Maintenance-phase: 3-5 g/day (single dose) for the duration of the supplementation period (Hultman et al., 1996). Note: Concurrent consumption with a mixed protein/CHO source ( $\sim 50 \mathrm{~g}$ of protein and $\mathrm{CHO})$ may enhance muscle creatine uptake via insulin stimulation (Steenge et al., 2000).

Performance impact Enhanced maximum isometric strength (Maganaris \& Maughan, 1998) and the acute performance of single and repeated bouts of high-intensity exercise ( $<150 \mathrm{~s}$ duration); most pronounced effects evident during tasks $<30 \mathrm{~s}$ (Branch, 2003; Lanhers et al., 2017). Chronic training adaptations include lean mass gains and improvements to muscular strength and power (Rawson \& Persky, 2007; Volek \& Rawson, 2004). Less common: Enhanced endurance performance resulting from increased/improved protein synthesis, glycogen storage, and thermoregulation (Cooper et al., 2012; Kreider et al., 2017). Potential antiinflammatory and anti-oxidant effects are noted (Deminice et al., 2013).

Further considerations No negative health effects are noted with long-term use (up to 4 years) when appropriate loading protocols are followed and potential side effects (Schilling et al., 2001). A potential 1-2 kg BM increase after creatine loading (primarily as a result of water retention; Deminice et al., 2013; Powers et al., 2003), may be detrimental for endurance performance or in events where the BM must be moved against gravity (e.g., high jump, pole vault) or where athletes must achieve a specific BM target.

\section{Nitrate}

Overview

Mechanism

Protocol of use

Performance impact
Dietary nitrate $\left(\mathrm{NO}_{3-}\right)$ is a popular supplement that has been commonly investigated to assess any benefits for prolonged submaximal exercise (Bailey et al., 2009) and high-intensity, intermittent, short-duration efforts (Thompson et al., 2015; Wylie et al., 2016). Enhances nitric oxide (NO) bioavailability via the $\mathrm{NO}_{3}$-nitrite-NO pathway, playing an important role in the modulation of skeletal muscle function (Jones, 2014a). Nitrate augments exercise performance via an enhanced function of type II muscle fibers (Bailey et al., 2015); a reduced ATP cost of muscle force production; an increased efficiency of mitochondrial respiration; an increased blood flow to the muscle; a decrease in blood flow to $\mathrm{VO}_{2}$ heterogeneities (Bailey et al., 2010).

High nitrate containing foods include leafy green and root vegetables, including spinach, rocket salad, celery, and beetroot. Acute performance benefits are generally seen within $2-3 \mathrm{hr}$ following a $\mathrm{NO}_{3-}$ bolus of 5-9 mmol (310-560 mg) (Hoon et al., 2014). Prolonged periods of $\mathrm{NO}_{3-}$ intake ( $>3$ days) also appears beneficial to performance (Thompson et al., 2015, 2016), and may be a positive strategy for highly-trained athletes, where performance gains from $\mathrm{NO}_{3}$ supplementation appear harder to obtain (Jones, 2014b).

Supplementation has been associated with improvements of 4-25\% in exercise time to exhaustion and of 1-3\% in sportspecific TT performances lasting <40 min in duration (Bailey et al., 2015; McMahon et al., 2016). Supplementation is proposed to enhance type II muscle fiber function (Bailey et al., 2015), resulting in the improvement (3-5\%) of high-intensity, intermittent, team-sport exercise of 12-40 min in duration (Thompson et al., 2015; Wylie et al., 2016). Evidence is equivocal for any benefit to exercise tasks lasting <12 min (Reynolds et al., 2016; Thompson et al., 2016). 


\title{
Table 3 (continued)
}

Further considerations and potential side effects
The available evidence suggests there appears to be few side effects or limitations to nitrate supplementation. There may exist the potential for GI upset in susceptible athletes, and should therefore be thoroughly trialed in training. There appears to be an upper limit to the benefits of consumption (i.e., no greater benefit from $16.8 \mathrm{mmol}$ [1,041 mg] vs. $8.4 \mathrm{mmol}$ [521 mg]; Wylie et al., 2013). Performance gains appear harder to obtain in highly-trained athletes (Jones, 2014b).

\begin{abstract}
Beta-Alanine
Overview

Beta-alanine augments intracellular buffering capacity, having potential beneficial effects on sustained high-intensity exercise performance.

Mechanism A rate-limiting precursor to the endogenous intracellular (muscle) buffer, carnosine; the immediate defense against proton accumulation in the contracting musculature during exercise (Lancha Junior et al., 2015). Chronic, daily supplementation of beta-alanine increases skeletal muscle carnosine content (Saunders et al., 2016).

Protocol of use Daily consumption of $\sim 65 \mathrm{mg} / \mathrm{kg} \mathrm{BM}$, ingested via a split-dose regimen (i.e., $0.8-1.6 \mathrm{~g}$ every 3-4 hr) over an extended supplement time frame of 10-12 weeks (Saunders et al., 2016).

Performance Impact Small but potentially meaningful performance benefits $(\sim 0.2-3 \%)$ during both continuous and intermittent exercise tasks of $30 \mathrm{~s}$ to $10 \mathrm{~min}$ in duration (Baguet et al., 2010; Chung et al., 2012; Saunders et al., 2016).

Further considerations A positive correlation between the magnitude of muscle carnosine change and performance benefit remains to be established and potential side effects (Saunders et al., 2016). Large interindividual variations in muscle carnosine synthesis have been reported (Nassis et al., 2016). The supplement effectiveness appears harder to realize in well-trained athletes (Bellinger, 2014). There is a need for further investigation to establish the practical use in various sport-specific situations (Hobson et al., 2012; Saunders et al., 2016). Possible negative side effects include skin rashes and/or transient paresthesia.
\end{abstract}

\section{Sodium Bicarbonate}

Overview

Sodium bicarbonate augments extracellular buffering capacity, having potential beneficial effects on sustained high-intensity exercise performance.

Mechanism

Acts as an extracellular (blood) buffer, aiding intracellular $\mathrm{pH}$ regulation by raising the extracellular $\mathrm{pH}$, and $\mathrm{HCO} 3-$ concentrations (Katz et al., 1984; Lancha Junior et al., 2015). The resultant pH gradient between the intracellular and extracellular environments leads to efflux of $\mathrm{H}+$ and La- from the exercising muscle (Katz et al., 1984; Mainwood et al., 1975).

Protocol of use Single acute NaHCO3 dose of 0.2-0.4 g/kg BM, consumed 60-150 min prior to exercise (Carr et al., 2011b; Siegler et al., 2012) Alternative strategies include: split doses (i.e., several smaller doses giving the same total intake) taken over a 30-180 min time period (Lambert et al., 1993); serial-loading with 3-4 smaller doses per day for 2-4 consecutive days prior to an event (Burke, 2013; Douroudos et al., 2006; Mc Naughton \& Thompson, 2001).

Performance impact Enhanced performance $(-2 \%)$ of short-term, high-intensity sprints lasting $\sim 60 \mathrm{~s}$ in duration, with a reduced efficacy as the effort duration exceeds 10 min (Carr et al., 2011b).

Further considerations Well-established GI distress may be associated with this supplement. Strategies to minimize GI upset include: co-ingestion and potential side effects with a small, carbohydrate-rich meal ( $1.5 \mathrm{~g} / \mathrm{kg}$ BM carbohydrates) (Carr et al., 2011c); the use of sodium citrate as an alternative (Requena et al., 2005); split-dose or stacking strategies (Burke, 2013; Douroudos et al., 2006; Mc Naughton \& Thompson, 2001). Given the high potential for GI distress, thorough investigation into the best individualized strategy is recommended prior to use in a competition setting.

Abbreviations: $\mathrm{ATP}=$ adenosine triphosphate; $\mathrm{BM}=$ body mass; $\mathrm{CHO}=$ carbohydrate $\mathrm{GI}=$ gastrointestinal; $\mathrm{TT}=$ time trial

\section{Supplements That Improve Performance Indirectly}

Many dietary supplements claim to enhance performance indirectly by supporting the athlete's health, body composition, and their ability to train hard, recover quickly, adapt optimally, avoid or recover from injury, and tolerate pain or soreness. Illness is a major problem for athletes if it interrupts training or occurs at a critical time, such as during a selection event or a major competition. Susceptibility to illness is increased in situations where athletes are involved in a high volume of training or competition and either intentionally or unintentionally experience deficits in energy intake (e.g., weight-loss diets), macronutrient intake (e.g. train-low or sleep-low-carbohydrate), and micronutrient status (e.g., vitamin D insufficiency in the winter) (Bermon et al., 2017). Athletes might benefit from nutritional supplements to support immunity in these scenarios and at other times when they are either susceptible to infection (e.g., during the common cold season and after long-haul travel) or suffering from an infection. Table 4 summarizes evidence for some of the commonly promoted "immune supportive" supplements, noting that the most promising candidates to assist in the prevention or treatment of upper respiratory symptoms are vitamin $\mathrm{D}$ and probiotics. Vitamin $\mathrm{C}$ during periods of heavy exertion and zinc lozenges at the onset of symptoms may be useful, but high doses of single antioxidants, particularly vitamin $\mathrm{C}$ and $\mathrm{E}$, may blunt exercise-induced training adaptations (Nikolaidis et al., 2012; Paulsen et al., 2014; Powers et al., 2011). Probiotic supplementation may reduce the incidence of travelers' diarrhea and gastrointestinal infection. Cochrane reviews have noted the low quality of many studies on nutritional supplements that are claimed to support immunity; specifically, small samples, poor controls, and unclear procedures for randomization and blinding were commonplace (Hao et al., 2015; Singh \& Das, 2013). Clearly, there is a pressing need for randomized controlled trials in highlevel athletes with sufficient participant numbers, rigorous controls and procedures, appropriate supplementation regimens, and clinically meaningful measures of immunity.

Supplements that assist an athlete to train harder, recover more quickly, and prevent injury or accelerate return to play when injury does occur can obviously enhance the athlete's preparation and, indirectly, their competition outcomes. Many products claim to 
Table 4 Nutritional Supplements for Immune Health in Athletes: Proposed Mechanism of Action and Evidence for Efficacy

\begin{tabular}{|c|c|}
\hline Supplement & Proposed Mechanism of Action \\
\hline Vitamin D & $\begin{array}{l}\text { An essential fat-soluble vitamin known to influence severa } \\
\text { aspects of immunity, particularly innate immunity (e.g., } \\
\text { expression of antimicrobial proteins). Skin exposure to } \\
\text { sunlight accounts for } 90 \% \text { of the source of vitamin D. }\end{array}$ \\
\hline
\end{tabular}

Probiotics

Probiotics are live microorganisms which, when adminisbeneficial bacteria in the gut. This has been associated with a URS incidence and $\sim 2$ day shortening of URS; minor side effects. range of potential benefits to gut health, as well as modulation More evidence is required supporting efficacy to reduce gastroof immune function.

\section{Evidence for Efficacy}

Moderate support. Evidence for deficiency in some athletes and soldiers, particularly in the winter (decreased skin sunlight exposure). Deficiency has been associated with increased URS. Recommend 1,000 IU/day $\mathrm{D}_{3}$ autumn-spring to maintain sufficiency. Further support required (He et al., 2016).

\section{Moderate support in ahletes with daily dose of $\sim 10^{10}$ live}

tered orally for several weeks, can increase the numbers of
beneficial bacteria in the gut. This has been associated with a
range of potential benefits to gut health, as well as modulation intestinal distress and infection (e.g., in a traveling athlete; Gleeson et al., 2011; Hao et al., 2015).

Vitamin C

Carbohydrate (drinks, gels)

Bovine colostrum

(e.g., Quercetin)

Echinacea

Omega-3 PUFAs
An essential water-soluble antioxidant vitamin that quenches ROS and augments immunity. Reduces interleukin-6 and cortisol responses to exercise in humans.
Maintains blood glucose during exercise, lowers stress hormones, and thus counters immune dysfunction.
Moderate support for preventing URS. Cochrane review of 5 studies in heavy exercisers $(n=598)$ shows $\sim 50 \%$ decrease in URS taking vitamin $\mathrm{C}(0.25-1.0 \mathrm{~g} /$ day $)$. Further support required. Unclear if antioxidants blunt adaptation in well-trained. Relatively small effects on cortisol compared with carbohydrate; immune measures no different from placebo. No support for treating URS. Cochrane reviews show no benefit of initiating vitamin $\mathrm{C}$ supplementation (>200 mg/day) after onset of URS (Hemila \& Chalker, 2013; Nieman et al., 2002).

Low-moderate support. Ingestion of carbohydrate (30-60 g/hr) attenuates stress hormone and some, but not all, immune perturbations during exercise. Very limited evidence that this modifies infection risk in athletes (Bermon et al., 2017; Walsh et al., 2011).

Low-moderate support that bovine colostrum blunts the decrease in saliva antimicrobial proteins after heavy exercise. Some evidence in small numbers of participants that bovine colostrum decreases URS. Further support required (Brinkworth \& Buckley, 2003; Davison \& Diment, 2010).

Low-moderate support. Human studies show some reduction in URS during short periods of intensified training and mild stimuPlant flavonoids. In vitro studies show strong antiinflammatory, anti-oxidant, and anti-pathogenic effects. Animal data indicate an increase in mitochondrial biogenesis and endurance performance.

lation of mitochondrial biogenesis and endurance performance, albeit in small numbers of untrained subjects. Limited influence on markers of immunity. Putative anti-viral effect for Quercetin. Further support required (Gleeson, 2016; Nieman et al., 2007).

An essential mineral that is claimed to reduce incidence and No support for preventing URS. High doses of zinc can decrease duration of colds. Zinc is required for DNA synthesis and as immune function and should be avoided. Moderate support for an enzyme cofactor for immune cells. Zinc deficiency results treating URS. Cochrane review shows benefit of zinc acetate in impaired immunity (e.g., lymphoid atrophy), and zinc deficiency is not uncommon in athletes. lozenges (75 mg) to decrease duration of URS; however, zinc must be taken $<24 \mathrm{hr}$ after onset of URS for duration of cold only. Side effects include bad taste and nausea (Singh \& Das, 2013).

Limited support. Supplementation before and after exercise does not alter immune perturbations. Some evidence of a reduction in for immune cells, particularly lymphocytes. Circulating glutamine is lowered after prolonged exercise and very heavy training.

Stimulant found in a variety of foods and drinks (e.g., coffee and sports drinks). Caffeine is an adenosine receptor antagonist and immune cells express adenosine receptors.

Herbal extract claimed to enhance immunity via stimulatory effects on macrophages. There is some in vitro evidence for this.

Found in fish oil. May influence immune function by acting as a fuel, in their role as membrane constituents or by regulating eicosanoid formation (e.g., prostaglandin). Prostaglandin is immunosuppressive. Claimed to exert anti-inflammatory effects postexercise. URS after endurance events in competitors receiving glutamine supplementation $(2 \times 5 \mathrm{~g})$. Mechanism for therapeutic effect requires investigation (Castell et al., 1996; Walsh et al., 1998).

Limited support. Evidence that caffeine supplementation activates lymphocytes and attenuates the fall in neutrophil function after exercise. Efficacy for altering URS in athletes remains unknown (Dulson \& Bishop, 2016; Walker et al., 2007).

Limited support. Early human studies indicated possible beneficial effects but more recent, larger scale, and better controlled studies indicate no effect of Echinacea on infection incidence or cold symptom severity (Karsch-Volk et al., 2015; Linde et al., 2006).

Limited support for blunting inflammation and functional changes after muscle-damaging eccentric exercise in humans and no evidence of reducing URS in athletes (Jakeman et al., 2017; Mickleborough, 2013). 
Table 4 (continued)

\begin{tabular}{|c|c|c|}
\hline Supplement & Proposed Mechanism of Action & Evidence for Efficacy \\
\hline Vitamin E & $\begin{array}{l}\text { An essential fat-soluble antioxidant vitamin that quenches } \\
\text { exercise-induced ROS and augments immunity. }\end{array}$ & $\begin{array}{l}\text { No support. Immune-enhancing effects in the frail elderly but no } \\
\text { benefit in young, healthy humans. One study actually showed that } \\
\text { vitamin E supplementation increased URS in those under heavy } \\
\text { exertion. High doses may be pro-oxidative (Hemila et al., 2003; } \\
\text { Meydani et al., 2004). }\end{array}$ \\
\hline$\beta$-glucans & $\begin{array}{l}\text { Polysaccharides derived from the cell walls of yeast, fungi, } \\
\text { algae, and oats that stimulate innate immunity. }\end{array}$ & $\begin{array}{l}\text { No support in humans. Effective in mice inoculated with influenza } \\
\text { virus; however, human studies with athletes show no benefits } \\
\text { (Nieman et al., 2008; Volman et al., 2008). }\end{array}$ \\
\hline
\end{tabular}

Abbreviations: PUFA = polyunsaturated fatty acids; ROS = reactive oxygen species; URS = upper respiratory symptoms.

provide benefits of this nature. Table 5 summarizes the evidence for some of the most popular compounds. Finally, the manipulation of body composition, including gaining lean (muscle) mass and reducing body fat levels, can contribute to performance in many events. This explains the large number of "weight gainers" and "fat burners" in the general and sports supplement market, though many of these are prohibited in sport. Protein is considered to be the premier ingredient in weight-gain-promoting supplements and evidence-based reviews conclude that protein is effective at promoting lean mass gain when combined with resistive exercise (Hector \& Philips, 2018). Evidence of efficacy for "fat burning" supplements is far from conclusive, however, and there is a complete absence of evidence for the effectiveness of the vast majority of supplements marketed in this category. Table 6 summarizes the evidence for some of the most common ingredients or products of this type (Hector \& Philips, 2018).

\section{Adverse Effects}

Adverse effects from the use of supplements may arise from a number of factors, including the safety and composition of the product per se and inappropriate patterns of use by athletes. Poor practices by athletes include the indiscriminate mixing and matching of many products without regard to total doses of some ingredients or problematic interactions between ingredients. Even commonly-used products may have negative side effects, especially when used outside the optimal protocol. For example, iron supplementation in those with already adequate iron stores can result in symptoms that may begin with vomiting, diarrhea, and abdominal pain, and develop to haemochromatosis and liver failure (Mettler \& Zimmermann, 2010). Bicarbonate may cause gastrointestinal distress when ingested in amounts sufficient to enhance performance; this can impair rather than improve performance and may counteract the benefits of other supplements taken at the same time (Carr et al., 2011a). The "more is better" philosophy, when applied to caffeine, may result in side effects, including nausea, anxiety, accelerated heart rate, and insomnia, which outweigh the performance benefits (Peeling et al., 2018). Unwanted outcomes become more common with caffeine doses $\geq 9 \mathrm{mg} / \mathrm{kg}$ body mass, but maximal benefits are usually achieved with intakes of $3-6 \mathrm{mg} / \mathrm{kg}$ (Burke, 2008). The possibility of more serious outcomes is illustrated by adverse, and potentially fatal, responses in two separate incidents in which very large doses (up to 30 grams) of caffeine were administered to healthy volunteers participating in laboratory studies (Bodkin, 2017). These incidents were due to errors in the dose calculation-if this can happen in a university research environment with supposed oversight by experienced staff, the potential clearly exists for similar errors by athletes and coaches.
Athletes and members of their support team should be aware of the regulations that govern the manufacture and marketing of supplements. According to the Dietary Supplements Health and Education Act 1994 (DSHEA) passed by US Congress, nutritional supplements sold in the United States that do not claim to diagnose, prevent, or cure disease are not subject to regulation by the Food and Drug Administration (FDA). Similar regulations apply in most other countries, where supplements are regulated in the same way as food ingredients and are therefore not subject to the stringent regulations that are applied to the pharmaceutical industry. This means that there is no requirement to prove claimed benefits, no requirement to show safety with acute or chronic administration, no quality assurance of content, and no liberal labeling requirements. It is well recognized that there are problems with some of the dietary supplements on sale, but the options open to those responsible for food safety are limited by the legislation that applies. The FDA regularly uses its powers to recall products in breach of the regulations, though they fully admit that their resources are insufficient for comprehensive monitoring, and recalls generally occur only after many people are harmed (https://www.fda.gov/food/ recallsoutbreaksemergencies/recalls/default.htm). The FDA have recently recalled supplement products containing excessive doses of vitamins A, D, B6, and selenium because of potentially toxic levels of these components. Examples of product complaints have included the presence of impurities, including lead, broken glass, and metal fragments, because of the failure of the producers to observe good manufacturing practice. The risk of gastrointestinal upset because of poor hygiene during the production and storage of products is also of concern. Although this may seem a minor inconvenience, and of similarity to food safety issues, the coincidence of problems around a crucial training period or competitive event may significantly interfere with an athlete's performance goals. It should be noted, though, that all of these problems are also regularly reported in normal foods.

Some supplements may actually cause harm to health, but these can be difficult to identify, and products are usually withdrawn only after a significant number of adverse events have occurred. For example, a range of products containing hydroxycitric acid were withdrawn from sale, but only after they were linked with the death of one consumer and with a substantial number of other cases of liver toxicity, cardiovascular problems, and seizures (https://www.fda.gov/NewsEvents/ PublicHealthFocus/ucm155817.htm). The extent of the problem is illustrated by the fact that, in the United States in 2015, approximately 23,000 emergency department visits annually are reported to be associated with dietary supplement use (Geller et al., 2015). This figure can be viewed as substantial, or it can be seen as small compared to the total number of adverse responses associated with the use of medications (Maughan et al., 2018). However, 
Table 5 Supplements That May Assist With Training Capacity, Recovery, Muscle Soreness, and Injury Management (see Rawson et al., 2018 for further details)

\begin{tabular}{l}
\hline Supplement \\
\hline Creatine monohydrate: \\
Creatine is a naturally occurring \\
nutrient, consumed in the diet, \\
and synthesized in the body. \\
Recommended supplement dose \\
is 20 g/day for 5 days, followed \\
by 3 to 5 g/day to increase and \\
maintain elevated body creatine \\
levels (Harris et al., 1992; \\
Hultman et al., 1996).
\end{tabular}

Beta-hydroxy betamethylbutyrate (HMB): HMB is a metabolite of the amino acid leucine. Manufacturer recommended dosage is $3 \mathrm{~g} /$ day.

\section{Proposed Mechanism of Action}

Enhanced adaptive response to exercise via increased growth factor/ gene expression, increased intracellular water; reduced symptoms of or enhanced recovery from muscledamaging exercise (e.g., DOMS); enhanced recovery from disuse or immobilization/ extreme inactivity; improved cognitive processing; decreased risk/enhanced recovery from mTBI

Enhanced adaptive response to exercise via decreased protein breakdown increased protein synthesis; increased cholesterol synthesis, increased growth hormone and IGF I mRNA, increased proliferation and differentiation of satellite cells, and inhibited apoptosis (reviewed in (Szczesniak et al., 2015).

Improved cognitive processing; decreased risk/enhanced recovery from mTBI; increased muscle protein synthesis; reduced symptoms of or enhanced recovery from muscledamaging exercise (e.g., DOMS).

\section{Evidence for Efficacy}

Many studies demonstrate improved training adaptations, such as increased lean mass or strength, indicating an enhanced adaptive response to exercise (Branch, 2003; Heaton et al., 2017; Rawson \& Volek, 2003). Reduced symptoms of, or enhanced recovery from, muscle-damaging exercise (e.g., DOMS) have been reported in some, but not all studies (reviewed in (Rawson et al., 2017). Enhanced recovery from disuse or immobilization/extreme inactivity has been reported in some, but not all studies (reviewed in Heaton et al., 2017). Improved cognitive processing is reported in most studies, especially when volunteers were fatigued by sleep deprivation or mental/physical tasks (reviewed in Gualano et al., 2012; 2016; Rae \& Broer, 2015; Rawson \& Venezia, 2011). The effects in athletes have not been well characterized, and only one group attempted to translate these effects into to athletic performance, albeit with a positive result. (Cook et al., 2011). Decreased damage and enhanced recovery from mTBI is supported by open label trials in children (Sakellaris et al., 2006, 2008) and using animal models (Sullivan et al., 2000). These data are not conclusive and more research is warranted. However, athletes at risk for concussion, who already ingest creatine supplements for performance or muscular benefits, may receive important brain benefits as well. A small increase in body mass is common with supplementation. This may be relevant for sports with weight classes/restrictions or where increased body mass may decrease performance.

Beneficial effects of HMB on strength and fat free mass are small, while the effects on muscle damage are unclear (Rowlands \& Thomson, 2009). Recent reports of "steroid-like" gains in strength, power, and fat free mass, and reductions in muscle damage from HMB-free acid (HMB-FA) supplementation (Lowery et al., 2016; Wilson et al., 2013, 2014) have not been reproduced and seem unlikely (Phillips et al., 2017). Potential use for HMB during extreme inactivity/disuse or recovery from injury, but these effects have only been described in older adults following 10 days of bed rest (Deutz et al., 2013). Benefits of HMB supplementation could most likely be obtained from normal dietary protein or whole protein supplements (Wilkinson et al., 2013), so HMB supplements may not be more effective than adhering to the current protein intake recommendations

Improved cognitive processing following omega 3-fatty acid supplementation shown in healthy older adults those with mild or severe cognitive impairment (reviewed in Barrett et al., 2014). It is not known if these benefits would occur in young, healthy athletes, or how this would translate to athletic performance. Animal data show that the structural damage and cognitive decline associated with mTBI are reduced/attenuated with omega-3 fatty acid supplementation when ingested either before or after the injury (reviewed in Barrett et al., 2014; Erdman et al., 2011; Tipton, 2015). Two case studies support these findings (Lewis et al., 2013; Roberts et al., 2008) and large, double-blind, placebo-controlled trials are currently under way (clinicaltrials.gov NCT101903525, NCT01814527). In muscle, omega-3 fatty acid supplementation can increase muscle protein synthesis (Smith et al., 2011a, 2011b), but this may not occur when protein is ingested after exercise in recommended amounts (Smith et al., 2011a, 2011b). Anti-inflammatory effects of omega-3 fatty acid intake may reduce muscle damage or enhance recovery from intense, eccentric exercise (e.g., decrease DOMS), but this is not a consistent finding (Gray et al., 2014; Jouris et al., 2011). No indication that decreased omega 3 -fatty acids in the body impair performance, and highdose supplements can cause some adverse effects (reviewed in (Erdman et al., 2011; Mickleborough, 2013), so the best recommendation may be to include rich sources of omega- 3 fatty acids, such as fatty fish, in the diet instead of supplements. Low risk but unclear if supplementation should be pursued by athletes, in lieu of including fatty fish in the diet as a source of omega-3 fatty acids. Fish oil or omega-3 fatty acid supplement consumption could include heavy metal contaminants, or cause bleeding, digestive problems, and/ or increased LDL. 
Table 5 (continued)

\begin{tabular}{|c|c|c|}
\hline Supplement & Proposed Mechanism of Action & Evidence for Efficacy \\
\hline $\begin{array}{l}\text { Vitamin D: An essential fat- } \\
\text { soluble vitamin. Skin exposure } \\
\text { to sunlight normally accounts for } \\
90 \% \text { of the source of vitamin D. }\end{array}$ & $\begin{array}{l}\text { Enhanced adaptive response to } \\
\text { exercise; decreased stress fractures }\end{array}$ & $\begin{array}{l}\text { Data on the effects of vitamin D supplementation on muscle function and } \\
\text { recovery are equivocal, with discrepancies likely explained by differences } \\
\text { in baseline vitamin D concentrations prior to supplementation (Close } \\
\text { et al., 2013, 2016; Owens et al., 2014, 2015). Collectively, these data } \\
\text { strongly suggest a role for adequate vitamin D in the adaptive process to } \\
\text { stressful exercise. Low vitamin D status is associated with a 3.6×higher } \\
\text { stress fracture risk in Finnish military recruits (Ruohola et al., 2006). US } \\
\text { Naval recruits supplemented with } 800 \text { IU/day of vitamin D3 and 2,000 mg } \\
\text { calcium reduced stress fracture incidence by } 20 \% \text { (Lappe et al., 2008). } \\
\text { More data are needed, but it appears that vitamin D status, relates to stress } \\
\text { fracture risk, and supplementation, when warranted, may reduce this risk. }\end{array}$ \\
\hline $\begin{array}{l}\text { Gelatin and vitamin C/ } \\
\text { collagen: Recommended dose is } \\
5 \text { to } 15 \mathrm{~g} \text { gelatin with } 50 \mathrm{mg} \\
\text { vitamin } \mathrm{C} \text { (Shaw et al., } 2017) \text {. } \\
\text { Collagen hydrolysate dose is } \\
\text { about } 10 \text { g/day (Clark et al., } \\
2008 \text {; McAlindon et al., 2011) }\end{array}$ & $\begin{array}{l}\text { Increased collagen production; } \\
\text { thickened cartilage; decreased joint } \\
\text { pain }\end{array}$ & $\begin{array}{l}\text { Gelatin and collagen supplements appear to be low risk. Few data } \\
\text { available (Clark et al., 2008; McAlindon et al., 2011; Shaw et al., 2017) } \\
\text { but increased collagen production and decreased pain seem possible. } \\
\text { Functional benefits, recovery from injury, and effects in elite athletes are } \\
\text { not known. }\end{array}$ \\
\hline $\begin{array}{l}\text { Anti-inflammatory supple- } \\
\text { ments: Curcumin (a constituent } \\
\text { of the spice turmeric) is often } \\
\text { ingested for anti-inflammatory } \\
\text { effects at a dose of about } 5 \mathrm{~g} / \text { day. } \\
\text { Tart cherry juice at a dose of } \\
\text { about } 250-350 \mathrm{~mL} \mathrm{(} 30 \mathrm{~mL} \text { if }\end{array}$ & $\begin{array}{l}\text { Anti-inflammatory effects; reduced } \\
\text { symptoms of or enhanced recovery } \\
\text { from muscle-damaging exercise } \\
\text { (e.g., DOMS) }\end{array}$ & $\begin{array}{l}\text { Decreases in inflammatory cytokines and/or indirect markers of muscle } \\
\text { damage with anti-inflammatory supplements such as curcumin (McFarlin } \\
\text { et al., 2016; Nicol et al., 2015; Sciberras et al., 2015) and tart cherry juice } \\
\text { (reviewed in Bell et al., 2014; Coelho Rabello Lima et al., 2015) have been } \\
\text { reported. Anti-inflammatory effects may be beneficial, although benefits } \\
\text { may be sport/training specific. More research is needed before these } \\
\text { compounds can be recommended to athletes. }\end{array}$ \\
\hline
\end{tabular}

concentrate) twice daily for 4 to 5 day before an athletic event or for 2 to 3 days afterwards to promote recovery.

Abbreviations: DOMS = delayed onset muscle soreness; $\mathrm{mTBI}=$ mild traumatic brain injury (concussion).

minor problems that do not require acute medical aid may still be sufficient to interrupt training or prevent participation, so this statistic probably underestimates the risk for athletes.

The biggest concern for athletes who compete under an antidoping code (usually the World Anti-Doping Code, as published by the World Anti-Doping Agency [WADA]) is that supplements can contain prohibited substances that result in an anti-doping rule violation (ADRV). Athletes - and their support teams - may be at risk for an ADRV if there is evidence that they have used or attempted to use products containing ingredients on the Prohibited List (www.wada.ama.org). A common problem is the recording of an adverse analytical finding (AAF) of a prohibited substance in a urine sample ("positive drug test") as a result of supplement use (Maughan, 2005). Millions of athletes may be subject to antidoping testing, although these are mostly professional-, national-, or international-level athletes. For these athletes in particular, even if the ingestion of the prohibited substance was unintentional, the rules of strict liability within the World Anti-Doping Code mean that an AAF will be recorded, and may mean the loss of medals won or records set, as well as financial sanctions and/or temporary or permanent suspension from competition. It also damages the athlete's reputation and may lead to loss of employment and income through failed sponsorship opportunities. Where there has been deliberate cheating or benefit accrued from the use of a prohibited substance, these penalties seem entirely appropriate, but it is undoubtedly true that some ADRVs can be attributed to the innocent ingestion of prohibited substances in dietary supplements, with catastrophic results for the athlete.

One cause of an AAF arising from supplement use relates to an athlete's failure to read product labels to recognize the presence of prohibited substances. Many athletes consider supplements to be "natural" or "regulated" and therefore safe. Other athletes are confused by the number of chemical names for some prohibited substances and thus fail to recognize them on the product label. However, the most worrying cause of an inadvertent AAF is the use of supplements that contain prohibited substances as an undeclared ingredient or contaminant. Since the publication of the seminal study on the presence of undeclared prohibited substances in supplements (Geyer et al., 2004), there have been numerous reports of supplement contamination (Maughan, 2005). Recent reviews suggest that this problem remains (LGC, 2017; Martinez-Sanz et al., 2017). It is difficult to gain a perspective of the true prevalence of supplement contamination. Although the original study reported that $\sim 15 \%$ of more than 600 products acquired from around the world contained undeclared prohormones (Geyer et al., 2004), this and other investigations rarely include a truly random sample of the supplements and sports foods used by athletes. Some individual products or categories of products can be considered inherently more at risk of contamination due to the country of origin, the manufacturer, the type of product, and the range of declared ingredients (https://www.usada.org/substances/ supplement-411/). Nevertheless, it should also be recognized that common supplements, including vitamin $\mathrm{C}$, multivitamins, and minerals, have also been found, albeit rarely, to contain prohibited substances (Geyer et al., 2008). The range of prohibited substances found as undeclared ingredients in supplements now includes products from many sections of the WADA's List of Prohibited Substances and Methods, including stimulants, anabolic agents, selective androgen receptor modulators, diuretics, anorectics, and $\beta 2$ agonists (Martinez-Sanz et al., 2017). 
Table 6 Supplements Promoted to Assist With Physique Changes: Gain in Lean Mass and Loss of Body Fat Mass (see Hector \& Phillips, 2018 for further details)

\begin{tabular}{l} 
Supplement \\
\hline Gaining lean body mass* \\
Protein \\
Usually comprised of isolated proteins from \\
various sources (whey and soy most common) \\
Recommended daily dose: $1.6 \mathrm{~g}$ protein $/ \mathrm{kg} / \mathrm{day}$ \\
optimal (up to $2.2 \mathrm{~g} / \mathrm{kg} /$ day with no adverse \\
effects) \\
Recommended per-meal doses: $0.3-0.5 \mathrm{~g}$ \\
protein $/ \mathrm{kg}$ ( $3-4$ times per day and in close \\
temporal proximity to exercise, with postex- \\
ercise being consistently shown to be \\
effective) \\
Leucine
\end{tabular}

\section{Losing fat mass**}

Protein

From increased dietary sources or supplemental isolated proteins

Pyruvate
Chromium
Green tea (polyphenol catechins and caffeine)

$\alpha$-Lipoic acid

Conjugated linoleic acid (CLA)

Konjac fiber (glucomannan)

Omega-3 polyunsaturated fatty acids

Chitosan

\section{Proposed Mechanism of Action}

Enhances lean mass gains when ingested during programs of resistance training due to increased provision of building blocks (amino acids) and leucine as a trigger for a rise in muscle protein synthesis and suppression of muscle protein breakdown

Stimulates muscle protein synthesis and suppresses protein breakdown (possibly through insulin)

Enhance fat mass loss and promotes retention of lean mass

No data

Potentiates biological actions of insulin Thermogenic agent and/or lipolyticenhancing agent

No clear role, but possible antioxidant

Changes membrane fluidity favoring enhanced fat oxidation

Water-soluble polysaccharide-dietary fiber

No clear role, but possible appetite suppression, improved blood flow, and/ or modulator of gene expression

Lipid-binding agent to reduce lipid absorption

\section{Evidence for Efficacy}

Meta-analyses focusing on younger and older participants have shown positive effects enhancing gains in muscle mass (Cermak et al., 2012; Morton et al., 2017), but effects are not large

Short-term mechanistic data available (Wilkinson et al., 2013), but no long-term trials showing efficacy (Aguiar et al., 2017)

Meta-analyses confirm small but significant effects of greater dietary protein in weight loss to enhance fat mass loss and promote lean mass retention (Krieger et al., 2006; Wycherley et al., 2012)

Small-to-trivial effect (Onakpoya et al., 2014a)

No effect (Tian et al., 2013)

Small-to-trivial effect (Jurgens et al., 2012)

Small-to-trivial effect (Kucukgoncu et al., 2017)

Small-to-trivial effect (Onakpoya et al., 2012)

Small-to-trivial effect (Onakpoya et al., 2014b)

Small-to-trivial effect (Zhang et al., 2017)

Small-to-trivial effect (Jull et al., 2008)

*In combination with progressive resistance exercise programs. **In combination with an exercise- and/or diet-induced energy deficit.

In some cases, the amount of the prohibited substance in a supplement may be high, even higher than the normal therapeutic dose. For example, Geyer et al. (2002) reported the analysis of metandienone (commonly known as methandrostenolone or Dianabol) in high amounts in a "body building" supplement from England. The recommended amount of the supplement would have supplied a dose of 10-43 mg; in comparison, the typical therapeutic dose of this drug was 2.5-5 mg/day (Goodman \& Gilman, 1975), though its medical use has been discontinued in most countries for many years. This amount would certainly have a potent anabolic effect, but would likely produce serious side effects, including psychiatric and behavioral effects and significant damage to a range of body systems including the liver (Solimini et al., 2017). Unlike many of the earlier cases involving steroids related to nandrolone and testosterone, this is not a trivial level of contamination and raises the possibility of deliberate adulteration of the product with the intention of producing a measurable effect on muscle strength and muscle mass. Most reports of adverse health outcomes resulting from supplement use have focused on liver problems of varying degrees of severity, but other organs are also affected. One epidemiological case-control study (Li et al., 2015) examined the association between use of muscle-building supplements and testicular germ cell cancer (TGCC) risk, with 356 TGCC cases and 513 controls from the Eastern United States. The odds ratio (OR) for the use of muscle-building supplements in relation to risk of TGCC was elevated $(\mathrm{OR}=1.65,95 \%$ confidence interval $[\mathrm{CI}]$ : 1.11-2.46), with significantly stronger associations for early users and longer periods of use.

Ironically, supplements that are contaminated with extremely small amounts of prohibited substances (too low to have any physiological effect) may still cause a positive doping outcome. For instance, ingestion of 19-norandrostenedione, a precursor of nandrolone, will result in the appearance in the urine of 19-norandrosterone, the diagnostic metabolite for nandrolone. If the urinary concentration of 19-norandrosterone exceeds $2 \mathrm{ng} / \mathrm{mL}$, an AAF is recorded (Baume et al., 2004). The addition of as little as $2.5 \mu \mathrm{g}$ of 19-norandrostenedione to a supplement can result in a urinary concentration of 19-norandrosterone that exceeds this 
threshold (Watson et al., 2009). These amounts are close to the limits of detection of the analytical methods currently applied to the analysis of dietary supplements, and are far below the levels of contamination deemed acceptable from a health and safety perspective.
Various efforts are being made to address the problems, including the use of third-party auditing activities to identify products that athletes may consider to be at "low risk" of containing prohibited substances. There can be no absolute guarantee that any

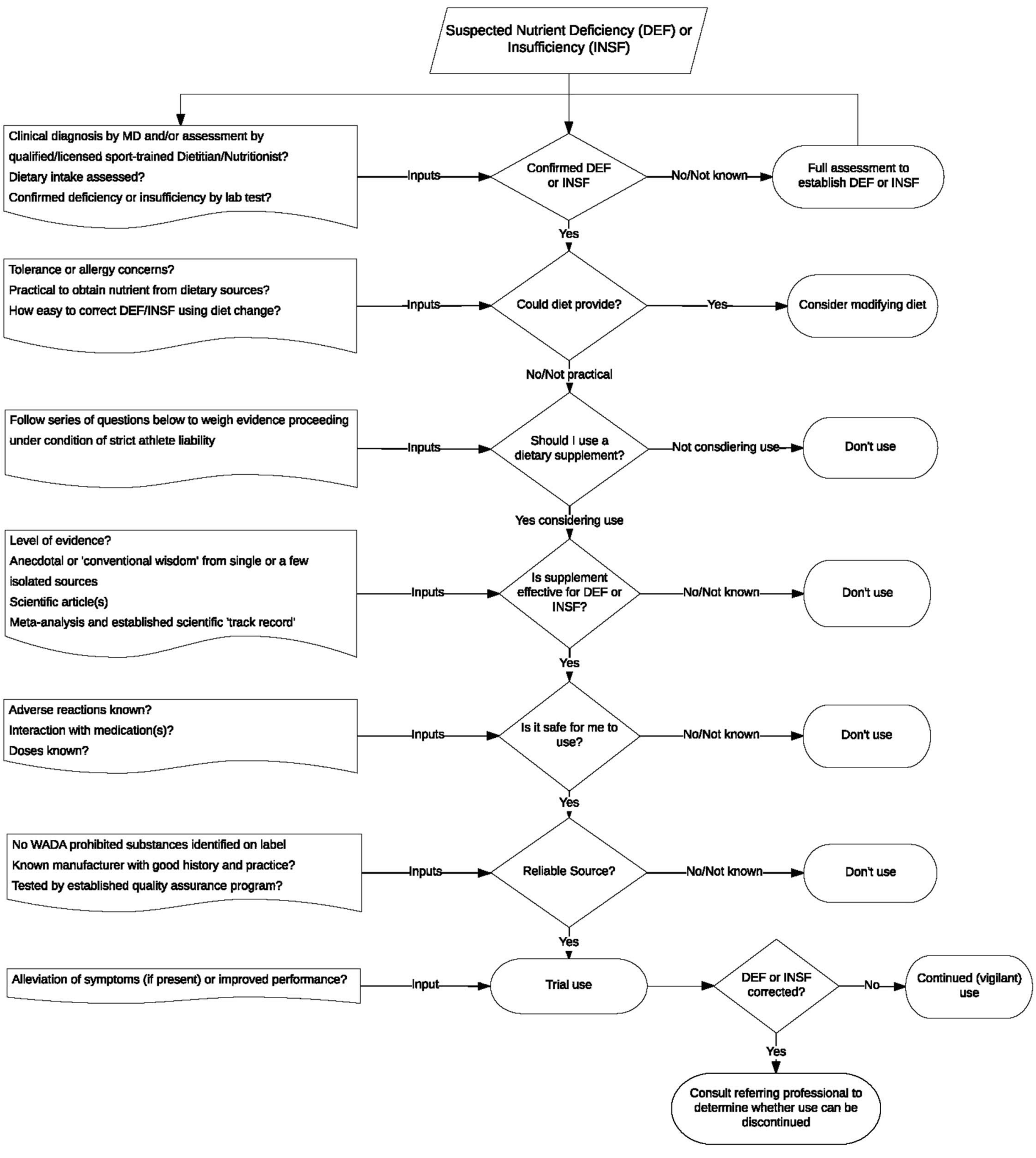

Figure 2 - Flow chart to guide informed decision making and reducing risk of ADRV during nutritional supplement use. 
product is entirely safe, but these schemes do help the athlete to manage the risk. Athletes contemplating the use of dietary supplements should consider very carefully whether the possible benefits outweigh the risks of a doping offense that might end their career.

\section{Practical Implications and Decision Tree}

Dietary supplements are an established part of the landscape of modern sport and are likely to remain so. Athletes who take
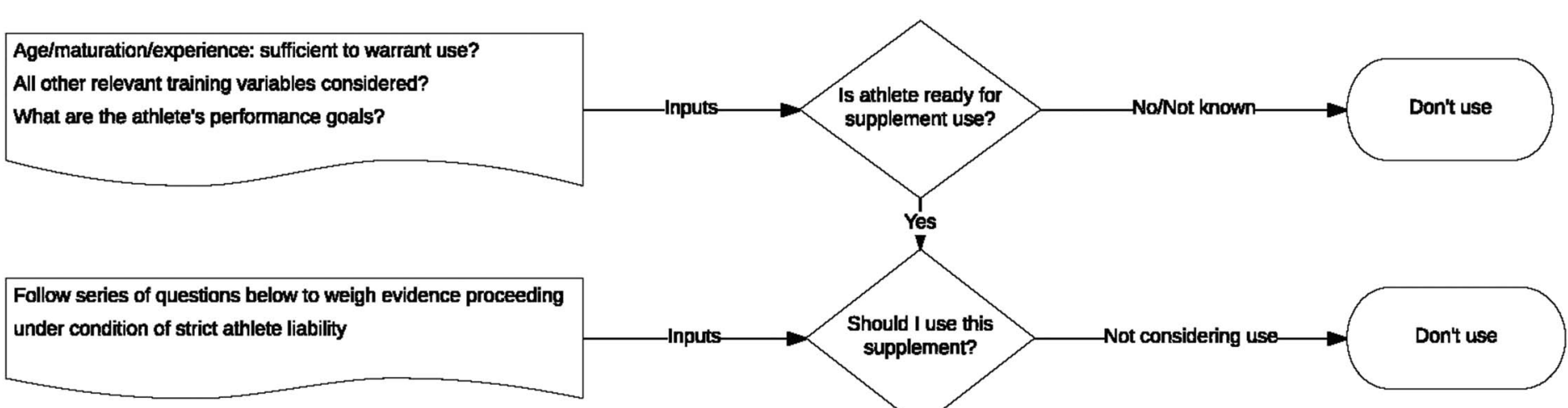

\section{Level of Evidence:}

Anecdotal or 'conventional wistom' from single or a few isolated sources

Scientific article(s)

Meta-analysis and established scientific 'track record'
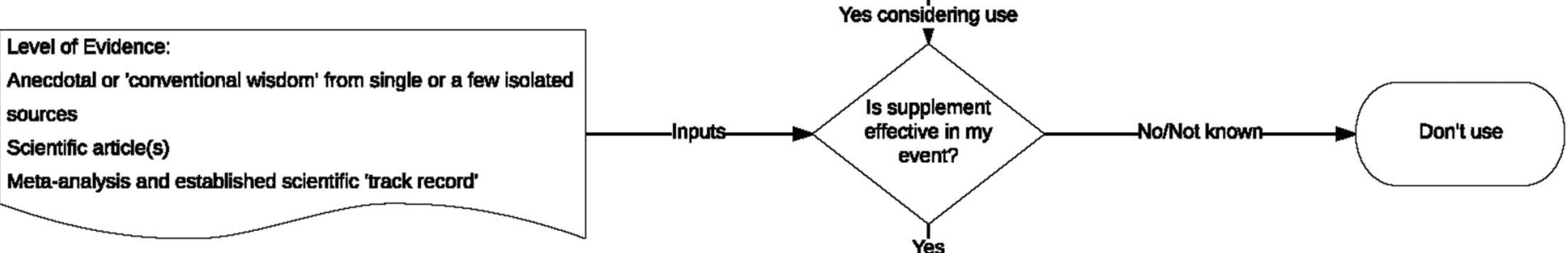

Adverse reactions known?

Interaction with medication?

Doses known?
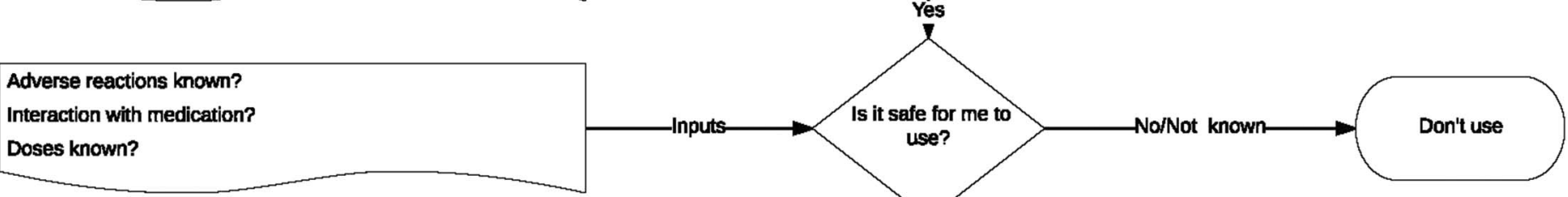

No WADA substances identified on label Known manufacturer with good history and practice? Tested by established quality assurance program?
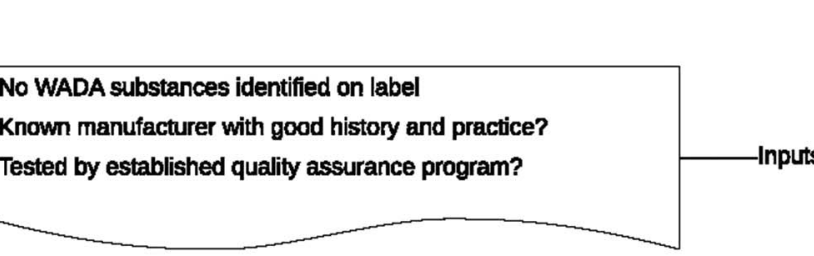

Trial in practice and/or less important compettition

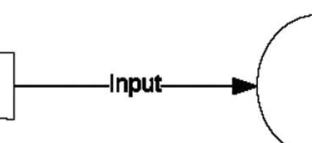

Use supplement

on trial basis

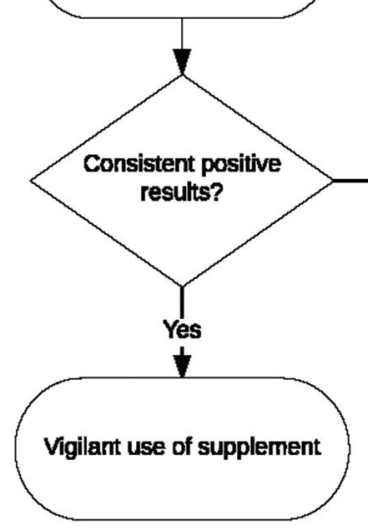

Don't use

Figure 3 - Flow chart to guide informed decision making and reducing risk of ADRV during ergogenic supplement use. 
supplements often have no clear understanding of the potential effects of supplements they are using, but supplements should be used only after a careful cost-benefit analysis has been conducted. On one side of the decision tree are the rewards, the most obvious of which are correction of nutrient deficiencies, achievement of nutritional goals, or enhancement of one or another physiological/ biochemical function to directly or indirectly improve performance. On the other side lie the costs - the possibility of using an ineffective supplement, the possible risks to health, and the potential for an ADRV. A flow of questions that could be posed in reaching an informed decision is shown in Figures 2 and 3.

In deciding whether to use a supplement, athletes should consider all aspects of their maturation in, and preparation for, their event to ensure that the supplement under consideration provides an advantage that no other strategy can address. Whether the supplement is practical to use should also be assessed: Is the product available, affordable, tolerated, and compatible with the athlete's other goals? The input of the athlete's coaching team and medical/science support network is important. Athletes who do not have regular access to such a network should consider decisions around supplement use as an important reason to consult an independent sports nutrition expert as well as a physician. Analysis of the evidence around the effectiveness of supplements and their safety is often difficult. A complete nutritional assessment may provide an appropriate justification for the specific use of nutritional supplements and sports foods. For a small number of sports supplements, there is good evidence of a performance effect or indirect benefit for some athletes in some specific situations with little or no risk of adverse outcomes (Peeling et al., 2018; Rawson et al., 2018). Professional advice is often important in ensuring that the athlete is sufficiently knowledgeable about the appropriate protocol for use of these supplements, but individual athletes may respond very differently to a given supplement, with some exhibiting a markedly beneficial effect while others experience no benefit or even a negative effect on performance. Furthermore, the situation in which the athlete wishes to use the supplement may differ in important ways from its substantiated use. Repeated trials may be necessary to establish whether a true effect, rather than just random variation, is seen in response to use of any novel intervention. Some trial and error may also be involved in fine tuning the supplement protocol to suit the needs of the specific situation of use or the individual athlete.

Evidence to support the effectiveness and safety of many of the supplements targeted at athletes, however, is largely absent. There seems to be little incentive for those selling supplements to invest the substantial sums needed to undertake detailed scientific evaluation of their products. Even where some evidence does exist, it may not be relevant to the high-performance athletes because of limitations in the study design (such as the specificity of the exercise tests), the study population, or the context of use. Failure to verify the composition of the supplements used may also give misleading results. It seems sensible to exercise caution when using supplements, as any compound that has the potential to enhance health or exercise performance by altering physiological function must also have the potential for adverse effects in some individuals. Athletes should see good evidence of a performance or other benefit, and should be confident that it will not be harmful to health, before accepting the financial cost and the health or performance risks associated with any supplement. Finally, the athlete should be sure, if supplements or sports foods are to be used, that they have undertaken due diligence to source products that are at low risk of containing prohibited substances.

\section{Conclusion}

Dietary supplements can play a small role in an athlete's sports nutrition plan, with products that include essential micronutrients, sports foods, performance supplements, and health supplements all potentially providing benefits. Some supplements, when used appropriately, may help athletes to meet sports nutrition goals, train hard, and stay healthy and injury free. A few supplements can directly enhance competition performance. However, it takes considerable effort and expert knowledge to identify which products are appropriate, how to integrate them into the athlete's sports nutrition plan, and how to ensure that any benefits outweigh the possible negative side effects, including the potential for an ADRV. A strict risk-benefit analysis involving a decision tree approach to the effectiveness, safety, and risks should identify the small number of products that may benefit the athlete. Such an analysis requires the input of a well-informed sports nutrition professional.

\section{References}

Aguiar, A.F., Grala, A.P., da Silva, R.A., Soares-Caldeira, L.F., Pacagnelli, F.L., Ribeiro, A.S., . . B Balvedi, M.C.W. (2017). Free leucine supplementation during an 8-week resistance training program does not increase muscle mass and strength in untrained young adult subjects. Amino Acids, 49(7), 1255-1262. PubMed doi:10.1007/s00726-017-2427-0

Baguet, A., Bourgois, J., Vanhee, L., Achten, E., \& Derave, W. (2010). Important role of muscle carnosine in rowing performance. Journal of Applied Physiology (1985), 109(4), 1096-1101. doi:10.1152/ japplphysiol.00141.2010

Bailey, R.L., Gahche, J.J., Lentino, C.V., Dwyer, J.T., Engel, J.S., Thomas, P.R., . . . Picciano, M.F. (2011). Dietary supplement use in the United States, 2003-2006. The Journal of Nutrition, 141(2), 261-266. doi:10.3945/jn.110.133025

Bailey, S.J., Fulford, J., Vanhatalo, A., Winyard, P.G., Blackwell, J.R., DiMenna, F.J., . . Jones, A.M. (2010). Dietary nitrate supplementation enhances muscle contractile efficiency during knee-extensor exercise in humans. Journal of Applied Physiology (1985), 109(1), 135-148. doi:10.1152/japplphysiol.00046.2010

Bailey, S.J., Varnham, R.L., DiMenna, F.J., Breese, B.C., Wylie, L.J., \& Jones, A.M. (2015). Inorganic nitrate supplementation improves muscle oxygenation, $\mathrm{O}(2)$ uptake kinetics, and exercise tolerance at high but not low pedal rates. Journal of Applied Physiology (1985), 118(11), 1396-1405. doi:10.1152/japplphysiol.01141.2014

Bailey, S.J., Winyard, P., Vanhatalo, A., Blackwell, J.R., Dimenna, F.J., Wilkerson, D.P., . . Jones, A.M. (2009). Dietary nitrate supplementation reduces the $\mathrm{O} 2$ cost of low-intensity exercise and enhances tolerance to high-intensity exercise in humans. Journal of Applied Physiology (1985), 107(4), 1144-1155. doi:10.1152/japplphysiol. 00722.2009

Barrett, E.C., McBurney, M.I., \& Ciappio, E.D. (2014). Omega-3 fatty acid supplementation as a potential therapeutic aid for the recovery from mild traumatic brain injury/concussion. Advances in Nutrition, 5(3), 268-277. doi:10.3945/an.113.005280

Baume, N., Avois, L., Schweizer, C., Cardis, C., Dvorak, J., Cauderay, M., . . . Saugy, M. (2004). [13C]Nandrolone excretion in trained athletes: Interindividual variability in metabolism. Clinical Chemistry, 50(2), 355-364. doi:10.1373/clinchem.2003.022848

Bell, P.G., McHugh, M.P., Stevenson, E., \& Howatson, G. (2014). The role of cherries in exercise and health. Scandinavian Journal of Medicine \& Sciences in Sports, 24(3), 477-490. doi:10.1111/sms.12085 
Bellinger, P.M. (2014). beta-Alanine supplementation for athletic performance: An update. Journal of Strength \& Conditioning Research, 28(6), 1751-1770. doi:10.1519/JSC.0000000000000327

Bermon, S., Castell, L.M., Calder, P.C., Bishop, N.C., Blomstrand, E., Mooren, F.C., . . . Nagatomi, R. (2017). Consensus statement immunonutrition and exercise. Exercise Immunology Review, 23, 8-50. PubMed

Bodkin, H. (2017). Students left fighting for lives after taking enough caffeine for 300 cups of coffee in botched university experiment. The Telegraph. Retrieved from http://www.telegraph.co.uk/news/2017/01/ 25/university-fined-400k-students-taking-part-caffeine-experiment/

Branch, J.D. (2003). Effect of creatine supplementation on body composition and performance: A meta-analysis. International Journal of Sport Nutrition and Exercise Metabolism, 13(2), 198-226.

Brinkworth, G.D., \& Buckley, J.D. (2003). Concentrated bovine colostrum protein supplementation reduces the incidence of self-reported symptoms of upper respiratory tract infection in adult males. European Journal of Nutrition, 42(4), 228-232. doi:10.1007/s00394-003-0410-x

Bruce, C.R., Anderson, M.E., Fraser, S.F., Stepto, N.K., Klein, R., Hopkins, W.G., \& Hawley, J.A. (2000). Enhancement of 2000-m rowing performance after caffeine ingestion. Medicine \& Science in Sports \& Exercise, 32(11), 1958-1963.

Buford, T.W., Kreider, R.B., Stout, J.R., Greenwood, M., Campbell, B., Spano, M., . . Antonio, J. (2007). International Society of Sports Nutrition position stand: Creatine supplementation and exercise. Journal of the International Society of Sports Nutrition, 4, 6. PubMed doi:10.1186/1550-2783-4-6

Burke, L.M. (2008). Caffeine and sports performance. Applied Physiology, Nutrition, and Metabolism, 33(6), 1319-1334. doi:10.1139/H08-130

Burke, L.M. (2013). Practical considerations for bicarbonate loading and sports performance. Nestle Nutrition Institute Workshop Series, 75, 15-26. doi:10.1159/000345814

Burke, L.M., \& Peeling, P. (2018). Methodologies for investigating performance changes with supplement use. International Journal of Sport Nutrition and Exercise Metabolism, 28(2). doi:10.1123/ ijsnem.2017-0325

Carr, A.J., Gore, C.J., \& Dawson, B. (2011a). Induced alkalosis and caffeine supplementation: Effects on 2,000-m rowing performance. International Journal of Sport Nutrition and Exercise Metabolism, 21(5), 357-364.

Carr, A.J., Hopkins, W.G., \& Gore, C.J. (2011b). Effects of acute alkalosis and acidosis on performance: A meta-analysis. Sports Medicine, 41. doi:10.2165/11591440-000000000-00000

Carr, A.J., Slater, G.J., Gore, C.J., Dawson, B., \& Burke, L.M. (2011c). Effect of sodium bicarbonate on $\left[\mathrm{HCO}^{-}\right], \mathrm{pH}$, and gastrointestinal symptoms. International Journal of Sport Nutrition and Exercise Metabolism, 21(3), 189-194.

Castell, L.M., Poortmans, J.R., \& Newsholme, E.A. (1996). Does glutamine have a role in reducing infections in athletes? European Journal of Applied Physiology, 73(5), 488-490.

Cermak, N.M., Res, P.T., de Groot, L.C., Saris, W.H., \& van Loon, L.J. (2012). Protein supplementation augments the adaptive response of skeletal muscle to resistance-type exercise training: A meta-analysis. The American Journal of Clinical Nutrition, 96(6), 1454-1464. PubMed

Chung, W., Shaw, G., Anderson, M.E., Pyne, D.B., Saunders, P.U., Bishop, D.J., \& Burke, L.M. (2012). Effect of 10 week beta-alanine supplementation on competition and training performance in elite swimmers. Nutrients, 4(10), 1441-1453. PubMed doi:10.3390/nu4101441

Clark, A., \& Mach, N. (2017). The crosstalk between the gut microbiota and mitochondria during exercise. Frontiers in Physiology, 8, 319. doi:10.3389/fphys.2017.00319
Clark, K.L., Sebastianelli, W., Flechsenhar, K.R., Aukermann, D.F., Meza, F., Millard, R.L., . . . Albert, A. (2008). 24-Week study on the use of collagen hydrolysate as a dietary supplement in athletes with activityrelated joint pain. Current Medical Research and Opinion, 24(5), 1485-1496. PubMed doi:10.1185/030079908X291967

Close, G.L., Hamilton, D.L., Philp, A., Burke, L.M., \& Morton, J.P. (2016). New strategies in sport nutrition to increase exercise performance. Free Radical Biology \& Medicine, 98, 144-158. doi:10.1016/ j.freeradbiomed.2016.01.016

Close, G.L., Russell, J., Cobley, J.N., Owens, D.J., Wilson, G., Gregson, W., . . Morton, J.P. (2013). Assessment of vitamin D concentration in non-supplemented professional athletes and healthy adults during the winter months in the UK: Implications for skeletal muscle function. Journal of Sports Sciences, 31(4), 344-353. doi:10.1080/ 02640414.2012.733822

Coelho Rabello Lima, L., Oliveira Assumpcao, C., Prestes, J., \& Sergio Denadai, B. (2015). Consumption of cherries as a strategy to attenuate exercise-induced muscle damage and inflammation in humans. $\mathrm{Nu}$ tricion Hospitalaria, 32(5), 1885-1893. PubMed doi:10.3305/nh. 2015.32.5.9709

Cook, C.J., Crewther, B.T., Kilduff, L.P., Drawer, S., \& Gaviglio, C.M. (2011). Skill execution and sleep deprivation: Effects of acute caffeine or creatine supplementation - a randomized placebocontrolled trial. Journal of the International Society of Sports Nutrition, 8, 2. PubMed doi:10.1186/1550-2783-8-2

Cooper, R., Naclerio, F., Allgrove, J., \& Jimenez, A. (2012). Creatine supplementation with specific view to exercise/sports performance: An update. Journal of the International Society of Sports Nutrition, 9(1), 33. PubMed doi:10.1186/1550-2783-9-33

Davison, G., \& Diment, B.C. (2010). Bovine colostrum supplementation attenuates the decrease of salivary lysozyme and enhances the recovery of neutrophil function after prolonged exercise. British Journal of Nutrition, 103(10), 1425-1432. PubMed doi:10.1017/ S0007114509993503

Deminice, R., Rosa, F.T., Franco, G.S., Jordao, A.A., \& de Freitas, E.C. (2013). Effects of creatine supplementation on oxidative stress and inflammatory markers after repeated-sprint exercise in humans. Nutrition, 29(9), 1127-1132. PubMed doi:10.1016/j.nut.2013.03.003

Deutz, N.E., Pereira, S.L., Hays, N.P., Oliver, J.S., Edens, N.K., Evans, C.M., \& Wolfe, R.R. (2013). Effect of beta-hydroxy-betamethylbutyrate (HMB) on lean body mass during 10 days of bed rest in older adults. Clinical Nutrition, 32(5), 704-712. doi:10.1016/ j.clnu.2013.02.011

Douroudos, I.I., Fatouros, I.G., Gourgoulis, V., Jamurtas, A.Z., Tsitsios, T., \& Hatzinikolaou, A. (2006). Dose-related effects of prolonged $\mathrm{NaHCO} 3$ ingestion during high-intensity exercise. Medicine \& Science in Sports \& Exercise, 38(10), 1746-1753. doi:10.1249/01.mss. 0000230210.60957 .67

Dulson, D.K., \& Bishop, N.C. (2016). Effect of a high and low dose of caffeine on human lymphocyte activation in response to antigen stimulation. Applied Physiology, Nutrition, and Metabolism, 41(2), 224-227. doi:10.1139/apnm-2015-0456

Erdman, J., Oria, M., \& Pillsbury, L. (2011). Nutrition and traumatic brain injury: Improving acute and subacute health coutcomes in military personnel. Washington, DC: National Academies Press.

Fennell, D. (2004). Determinants of supplement usage. Preventive Medicine, 39(5), 932-939. PubMed doi:10.1016/j.ypmed.2004.03. 031

French, C., McNaughton, L., Davies, P., \& Tristram, S. (1991). Caffeine ingestion during exercise to exhaustion in elite distance runners. Revision. The Journal of Sports Medicine and Physical Fitness, $31(3), 425-432$. 
Ganio, M.S., Klau, J.F., Casa, D.J., Armstrong, L.E., \& Maresh, C.M. (2009). Effect of caffeine on sport-specific endurance performance: A systematic review. The Journal of Strength \& Conditioning Research, 23(1), 315-324. PubMed doi:10.1519/JSC.0b013e31818b979a

Garthe, I., \& Maughan, R.J. (2018). Athletes and supplements: Prevalance and perspectives. International Journal of Sport Nutrition and Exercise Metabolism, 28(2). doi:10.1123/ijsnem.2017-0429

Geller, A.I., Shehab, N., Weidle, N.J., Lovegrove, M.C., Wolpert, B.J., Timbo, B.B., . . . Budnitz, D.S. (2015). Emergency department visits for adverse events related to dietary supplements. The New England Journal of Medicine, 373(16), 1531-1540. PubMed doi:10.1056/ NEJMsa1504267

Geyer, H., Bredehoft, M., Marek, U., Parr, M.K., \& Schanzer, W. (2002). Hohe Dosen des Anabolikums Metandienon in Nahrungserganzungsmitteln. Deutsche Apotheke Zeitung, 142, 29.

Geyer, H., Parr, M.K., Koehler, K., Mareck, U., Schanzer, W., \& Thevis, M. (2008). Nutritional supplements cross-contaminated and faked with doping substances. Journal of Mass Spectrometry, 43(7), 892902. PubMed doi:10.1002/jms. 1452

Geyer, H., Parr, M.K., Mareck, U., Reinhart, U., Schrader, Y., \& Schanzer, W. (2004). Analysis of non-hormonal nutritional supplements for anabolic-androgenic steroids - results of an international study. International Journal of Sports Medicine, 25(2), 124-129. PubMed doi:10.1055/s-2004-819955

Gibson, R.S. (2005). Principles of nutritional assessment (2nd ed.). New York, NY: Oxford University Press.

Gleeson, M. (2016). Immunological aspects of sport nutrition. Immunology and Cell Biology, 94, 117-123. PubMed doi:10.1038/icb.2015. 109

Gleeson, M., Bishop, N.C., Oliveira, M., \& Tauler, P. (2011). Daily probiotic's (Lactobacillus casei Shirota) reduction of infection incidence in athletes. International Journal of Sport Nutrition and Exercise Metabolism, 21(1), 55-64.

Goodman, L.S., \& Gilman, A. (1975). Pharmacological basis of therapeutics (5th ed., p. 1462). London/Toronto: Macmillan Publishing Co.

Gray, P., Chappell, A., Jenkinson, A.M., Thies, F., \& Gray, S.R. (2014). Fish oil supplementation reduces markers of oxidative stress but not muscle soreness after eccentric exercise. International Journal of Sport Nutrition and Exercise Metabolism, 24(2), 206-214. doi:10. 1123/ijsnem.2013-0081

Gualano, B., Rawson, E.S., Candow, D.G., \& Chilibeck, P.D. (2016). Creatine supplementation in the aging population: Effects on skeletal muscle, bone and brain. Amino Acids, 48(8), 1793-1805. PubMed doi:10.1007/s00726-016-2239-7

Gualano, B., Roschel, H., Lancha, A.H., Jr., Brightbill, C.E., \& Rawson, E.S. (2012). In sickness and in health: The widespread application of creatine supplementation. Amino Acids, 43(2), 519-529. PubMed doi:10.1007/s00726-011-1132-7

Hao, Q., Dong, B.R., \& Wu, T. (2015). Probiotics for preventing acute upper respiratory tract infections. The Cochrane Database of Systematic Reviews, (2), CD006895. doi:10.1002/14651858. CD006895.pub3

Harris, R.C., Söderlund, K., \& Hultman, E. (1992). Elevation of creatine in resting and exercised muscle of normal subjects by creatine supplementation. Clinical Sciences (Lond), 83(3), 367-374.

He, C.S., Aw Yong, X.H., Walsh, N.P., \& Gleeson, M. (2016). Is there an optimal vitamin D status for immunity in athletes and military personnel? Exercise Immunology Review, 22, 42-64.

Heaney, R.P. (2008). Vitamin D: Criteria for safety and efficacy. Nutrition Reviews, 66(10 Suppl. 2), S178-S181. PubMed doi:10.1111/j.17534887.2008.00102.x
Heaton, L.E., Davis, J.K., Rawson, E.S., Nuccio, R.P., Witard, O.C., Halson, S.L., . . Carter, J.M. (2017). In season nutritional strategies to enhance recovery for team sport athletes. Sports Medicine, 47(11), 2201-2218. PubMed

Hector, A.J., \& Philips, S.M. (2018). Protein recommendations for weight loss in elite athletes: A focus on body composition and performance. International Journal of Sport Nutrition and Exercise Metabolism, 28(2). doi:10.1123/ijsnem.2017-0273

Hemila, H., \& Chalker, E. (2013). Vitamin C for preventing and treating the common cold. The Cochrane Database of Systematic Reviews, (1), CD000980. doi:10.1002/14651858.CD000980.pub4

Hemila, H., Virtamo, J., Albanes, D., \& Kaprio, J. (2003). Physical activity and the common cold in men administered vitamin E and betacarotene. Medicine \& Science in Sports \& Exercise, 35(11), 18151820. PubMed doi:10.1249/01.MSS.0000093616.60899.92

Hobson, R.M., Saunders, B., Ball, G., Harris, R.C., \& Sale, C. (2012). Effects of beta-alanine supplementation on exercise performance: A meta-analysis. Amino Acids, 43(1), 25-37. PubMed doi:10.1007/ s00726-011-1200-Z

Hoon, M.W., Jones, A.M., Johnson, N.A., Blackwell, J.R., Broad, E.M., Lundy, B., . . Burke, L.M. (2014). The effect of variable doses of inorganic nitrate-rich beetroot juice on simulated 2, 000-m rowing performance in trained athletes. International Journal of Sports Physiology and Performance, 9(4), 615-620. PubMed doi:10. 1123/ijspp.2013-0207

Hossein-Nezhad, A., \& Holick, M.F. (2013). Vitamin D for health: A global perspective. Mayo Clinic Proceedings, 88(7), 720-755. PubMed doi:10.1016/j.mayocp.2013.05.011

Hultman, E., Soderlund, K., Timmons, J.A., Cederblad, G., \& Greenhaff, P.L. (1996). Muscle creatine loading in men. Journal of Applied Physiology (1985), 81(1), 232-237.

Jakeman, J.R., Lambrick, D.M., Wooley, B., Babraj, J.A., \& Faulkner, J.A. (2017). Effect of an acute dose of omega-3 fish oil following exerciseinduced muscle damage. European Journal of Applied Physiology, 117(3), 575-582. doi:10.1007/s00421-017-3543-y

Jones, A.M. (2014a). Dietary nitrate supplementation and exercise performance. Sports Medicine, 44(Suppl. 1), S35-S45.

Jones, A.M. (2014b). Influence of dietary nitrate on the physiological determinants of exercise performance: A critical review. Applied Physiology, Nutrition, and Metabolism, 39(9), 1019-1028.

Jouris, K.B., McDaniel, J.L., \& Weiss, E.P. (2011). The effect of omega-3 fatty acid supplementation on the inflammatory response to eccentric strength exercise. Journal of Sports Sciences Medicine, 10(3), 432-438.

Jull, A.B., Ni Mhurchu, C., Bennett, D.A., Dunshea-Mooij, C.A., \& Rodgers, A. (2008). Chitosan for overweight or obesity. The Cochrane Database of Systematic Reviews, (3), Cd003892. doi: 10.1002/14651858.CD003892.pub3

Jurgens, T.M., Whelan, A.M., Killian, L., Doucette, S., Kirk, S., \& Foy, E. (2012). Green tea for weight loss and weight maintenance in overweight or obese adults. The Cochrane Database of Systematic Reviews, (12), CD008650. doi:10.1002/14651858.CD008650.pub2

Karsch-Volk, M., Barrett, B., \& Linde, K. (2015). Echinacea for preventing and treating the common cold. JAMA, 313(6), 618-619. PubMed doi:10.1001/jama.2014.17145

Katz, A., Costill, D.L., King, D.S., Hargreaves, M., \& Fink, W.J. (1984). Maximal exercise tolerance after induced alkalosis. International Journal of Sports Medicine, 5(2), 107-110. PubMed doi:10.1055/ s-2008-1025890

Kreider, R.B., Kalman, D.S., Antonio, J., Ziegenfuss, T.N., Wildman, R., Collins, R., . . . Lopez, H.L. (2017). International Society of Sports Nutrition position stand: Safety and efficacy of creatine 
supplementation in exercise, sport, and medicine. Journal of the International Society of Sports Nutrition, 14, 18. PubMed doi:10. 1186/s12970-017-0173-Z

Krieger, J.W., Sitren, H.S., Daniels, M.J., \& Langkamp-Henken, B. (2006). Effects of variation in protein and carbohydrate intake on body mass and composition during energy restriction: A metaregression. American Journal of Clinical Nutrition, 83(2), 260274. PubMed

Kucukgoncu, S., Zhou, E., Lucas, K.B., \& Tek, C. (2017). Alpha-lipoic acid (ALA) as a supplementation for weight loss: Results from a meta-analysis of randomized controlled trials. Obesity Reviews, 18(5), 594-601. PubMed doi:10.1111/obr.12528

Lambert, C.P., Greenhaff, P.L., Ball, D., \& Maughan, R.J. (1993). Influence of sodium bicarbonate ingestion on plasma ammonia accumulation during incremental exercise in man. European Journal of Applied Physiology and Occupational Physiology, 66(1), 49-54. PubMed

Lancha Junior, A.H., Painelli Vde, S., Saunders, B., \& Artioli, G.G. (2015). Nutritional strategies to modulate intracellular and extracellular buffering capacity during high-intensity exercise. Sports Medicine, 45(Suppl. 1), S71-S81. PubMed doi:10.1007/s40279015-0397-5

Lanhers, C., Pereira, B., Naughton, G., Trousselard, M., Lesage, F.X., \& Dutheil, F. (2017). Creatine supplementation and upper limb strength performance: A systematic review and meta-analysis. Sports Medicine, 47(1), 163-173. PubMed doi:10.1007/s40279-016-0571-4

Lappe, J., Cullen, D., Haynatzki, G., Recker, R., Ahlf, R., \& Thompson, K. (2008). Calcium and vitamin D supplementation decreases incidence of stress fractures in female navy recruits. Journal of Bone and Mineral Research, 23(5), 741-749. doi:10.1359/jbmr.080102

Larson-Meyer, D.E.,Woolf, K., \& Burke, L.M., (2018). Assessment of nutrient status in athletes and the need for supplementation. International Journal of Sport Nutrition and Exercise Metabolism, 28(2). doi:10.1123/ijsnem.2017-0338

Larson-Meyer, D.E., \& Willis, K.S. (2010). Vitamin D and athletes. Current Sports Medicine Reports, 9(4), 220-226. PubMed

Lewis, M., Ghassemi, P., \& Hibbeln, J. (2013). Therapeutic use of omega3 fatty acids in severe head trauma. American Journal of Emergency Medicine, 31(1), 273.e5-273.e8. doi:10.1016/j.ajem.2012.05.014

LGC. (2017). Australian supplement survey summary. Retrieved from http://www2.lgcgroup.com/australiansupplementsurvey

Li, N., Hauser, R., Holford, T., Zhu, Y., Zhang, Y., Bassig, B.A., . . . Zheng, T. (2015). Muscle-building supplement use and increased risk of testicular germ cell cancer in men from Connecticut and Massachusetts. British Journal of Cancer, 112(7), 1247-1250. PubMed doi:10.1038/bjc.2015.26

Linde, K., Barrett, B., Wolkart, K., Bauer, R., \& Melchart, D. (2006). Echinacea for preventing and treating the common cold. The Cochrane Database of Systematic Reviews, (1), CD000530. doi:10. 1002/14651858.CD000530.pub2

Lowery, R.P., Joy, J.M., Rathmacher, J.A., Baier, S.M., Fuller, J.C., Jr., Shelley, M.C., . . . Wilson, J.M. (2016). Interaction of beta-hydroxybeta-methylbutyrate free acid and adenosine triphosphate on muscle mass, strength, and power in resistance trained individuals. The Journal of Strength \& Conditioning Research, 30(7), 1843-1854. PubMed

Maganaris, C.N., \& Maughan, R.J. (1998). Creatine supplementation enhances maximum voluntary isometric force and endurance capacity in resistance trained men. Acta Physiologica Scandinavica, 163(3), 279-287. PubMed doi:10.1046/j.1365-201x.1998.00395.x

Mainwood, G.W., \& Worsley-Brown, P. (1975). The effects of extracellular $\mathrm{pH}$ and buffer concentration on the efflux of lactate from frog sartorius muscle. The Journal of Physiology, 250(1), 1-22. PubMed

Martinez-Sanz, J.M., Sospedra, I., Ortiz, C.M., Baladia, E., Gil-Izquierdo, A., \& Ortiz-Moncada, R. (2017). Intended or unintended doping? A review of the presence of doping substances in dietary supplements used in sports. Nutrients, 9(10). doi:10.3390/nu9101093

Maughan, R.J. (2005). Contamination of dietary supplements and positive drug tests in sport. Journal of Sports Sciences, 23(9), 883-889. doi: 10.1080/02640410400023258

Maughan, R.J., Depiesse, F., \& Geyer, H. (2007). The use of dietary supplements by athletes. Journal of Sports Sciences, 25(Suppl. 1), S103-S113. doi:10.1080/02640410701607395

Maughan, R.J., \& Griffin, J. (2003). Caffeine ingestion and fluid balance: A review. Journal of Human Nutrition and Dietetics, 16(6), 411-420. PubMed

Maughan, R.J., Shirreffs, S.M., \& Vernec, A. (2018). Making decisions about supplement use. International Journal of Sport Nutrition and Exercise Metabolism, 28(2). doi:10.1123/ijsnem.2018-0009

McAlindon, T.E., Nuite, M., Krishnan, N., Ruthazer, R., Price, L.L., Burstein, D., . . . Flechsenhar, K. (2011). Change in knee osteoarthritis cartilage detected by delayed gadolinium enhanced magnetic resonance imaging following treatment with collagen hydrolysate: A pilot randomized controlled trial. Osteoarthritis Cartilage, 19(4), 399-405. PubMed doi:10.1016/j.joca.2011.01.001

McFarlin, B.K., Venable, A.S., Henning, A.L., Sampson, J.N., Pennel, K., Vingren, J.L., \& Hill, D.W. (2016). Reduced inflammatory and muscle damage biomarkers following oral supplementation with bioavailable curcumin. BBA Clinical, 5, 72-78. PubMed doi:10. 1016/j.bbacli.2016.02.003

McMahon, N.F., Leveritt, M.D., \& Pavey, T.G. (2016). The effect of dietary nitrate supplementation on endurance exercise performance in healthy adults: A systematic review and meta-analysis. Sports Medicine, 47(4), 735-756. doi:10.1007/s40279-016-0617-7

Mc Naughton, L., \& Thompson, D. (2001). Acute versus chronic sodium bicarbonate ingestion and anaerobic work and power output. The Journal of Sports Medicine and Physical Fitness, 41(4), 456-462. PubMed

Mettler, S., \& Zimmermann, M.B. (2010). Iron excess in recreational marathon runners. European Journal of Clinical Nutrition, 64(5), 490-494. PubMed doi:10.1038/ejcn.2010.16

Meydani, S.N., Han, S.N., \& Hamer, D.H. (2004). Vitamin E and respiratory infection in the elderly. Annals of the New York Academy of Sciences, 1031, 214-222. PubMed doi:10.1196/annals.1331.021

Mickleborough, T.D. (2013). Omega-3 polyunsaturated fatty acids in physical performance optimization. International Journal of Sport Nutrition and Exercise Metabolism, 23(1), 83-96. PubMed

Morton, R.W., Murphy, K.T., McKellar, S.R., Schoenfeld, B.J., Henselmans, M., Helms, E., . . Phillips, S.M. (2017). A systematic review, meta-analysis and meta-regression of the effect of protein supplementation on resistance training-induced gains in muscle mass and strength in healthy adults. British Journal of Sports Medicine. doi:10.1136/bjsports-2017-097608

Nassis, G.P., Sporer, B., \& Stathis, C.G. (2016). Beta-alanine efficacy for sports performance improvement: From science to practice. British Journal of Sports Medicine. doi:10.1136/bjsports-2016-097038

Nicol, L.M., Rowlands, D.S., Fazakerly, R., \& Kellett, J. (2015). Curcumin supplementation likely attenuates delayed onset muscle soreness (DOMS). European Journal of Applied Physiology, 115(8), 1769-1777. doi:10.1007/s00421-015-3152-6

Nieman, D.C., Henson, D.A., Gross, S.J., Jenkins, D.P., Davis, J.M., Murphy, E.A., . . . Mayer, E.P. (2007). Quercetin reduces illness but not immune perturbations after intensive exercise. 
Medicine \& Science in Sports \& Exercise, 39(9), 1561-1569. doi:10. 1249/mss.0b013e318076b566

Nieman, D.C., Henson, D.A., McAnulty, S.R., McAnulty, L., Swick, N.S., Utter, A.C., . . . Morrow, J.D. (2002). Influence of vitamin C supplementation on oxidative and immune changes after an ultramarathon. Journal of Applied Physiology, 92(5), 1970-1977. doi:10. 1152/japplphysiol.00961.2001

Nieman, D.C., Henson, D.A., McMahon, M., Wrieden, J.L., Davis, J.M., Murphy, E.A., . . . Dumke, C.L. (2008). Beta-glucan, immune function, and upper respiratory tract infections in athletes. Medicine \& Science in Sports \& Exercise, 40(8), 1463-1471. doi:10.1249/ MSS.0b013e31817057c2

Nikolaidis, M.G., Kerksick, C.M., Lamprecht, M., \& McAnulty, S.R. (2012). Does vitamin C and E supplementation impair the favorable adaptations of regular exercise? Oxidative Medicine and Cellular Longevity, 2012, 707941. PubMed doi:10.1155/2012/707941

Office of Dietary Supplements, National Institutes of Health. (1994). Dietary supplement health and education act of 1994. Retrieved from https:// ods.od.nih.gov/About/DSHEA_Wording.aspx

Onakpoya, I., Hunt, K., Wider, B., \& Ernst, E. (2014a). Pyruvate supplementation for weight loss: A systematic review and meta-analysis of randomized clinical trials. Critical Reviews in Food Science and Nutrition, 54(1), 17-23. doi:10.1080/10408398.2011.565890

Onakpoya, I., Posadzki, P., \& Ernst, E. (2014b). The efficacy of glucomannan supplementation in overweight and obesity: A systematic review and meta-analysis of randomized clinical trials. The Journal of the American College of Nutrition, 33(1), 70-78. doi:10.1080/ 07315724.2014 .870013

Onakpoya, I.J., Posadzki, P.P., Watson, L.K., Davies, L.A., \& Ernst, E. (2012). The efficacy of long-term conjugated linoleic acid (CLA) supplementation on body composition in overweight and obese individuals: A systematic review and meta-analysis of randomized clinical trials. European Journal of Nutrition, 51(2), 127-134. doi: 10.1007/s00394-011-0253-9

Owens, D.J., Sharples, A.P., Polydorou, I., Alwan, N., Donovan, T., Tang, J., . . . Close, G.L. (2015). A systems-based investigation into vitamin $\mathrm{D}$ and skeletal muscle repair, regeneration, and hypertrophy. American Journal of Physiology-Endocrinology and Metabolism, 309(12), E1019-E1031. PubMed doi:10.1152/ajpendo.00375. 2015

Owens, D.J., Webber, D., Impey, S.G., Tang, J., Donovan, T.F., Fraser, W.D., . . Close, G.L. (2014). Vitamin D supplementation does not improve human skeletal muscle contractile properties in insufficient young males. European Journal of Applied Physiology, 114(6), 1309-1320. doi:10.1007/s00421-014-2865-2

Paton, C., Costa, V., \& Guglielmo, L. (2015). Effects of caffeine chewing gum on race performance and physiology in male and female cyclists. Journal of Sports Sciences, 33(10), 1076-1083. doi:10.1080/ 02640414.2014.984752

Paulsen, G., Cumming, K.T., Holden, G., Hallen, J., Ronnestad, B.R., Sveen, O., . . . Raastad, T. (2014). Vitamin C and E supplementation hampers cellular adaptation to endurance training in humans: A double-blind, randomised, controlled trial. Journal of Physiology, 592(8), 1887-1901. doi:10.1113/jphysiol.2013.267419

Peake, J.M., Neubauer, O., Walsh, N.P., \& Simpson, R.J. (2017). Recovery of the immune system after exercise. Journal of Applied Physiology (1985), 122(5), 1077-1087. doi:10.1152/japplphysiol.00622. 2016

Peeling, P., Binnie, M., Goods, P.S.R., Sim, M., \& Burke, L.M. (2018). Evidence-based supplements for the enhancement of athletic performance. International Journal of Sport Nutrition and Exercise Metabolism, 28(2). doi:10.1123/ijsnem.2017-0343
Phillips, S.M., Aragon, A.A., Arciero, P.J., Arent, S.M., Close, G.L., Hamilton, D.L., . . . Willoughby, D.S. (2017). Changes in body composition and performance with supplemental HMB-FA + ATP. Journal of Strength \& Conditioning Research, 31(5):e71-e72. doi:10. 1519/jsc.0000000000001760

Powers, M.E., Arnold, B.L., Weltman, A.L., Perrin, D.H., Mistry, D., Kahler, D.M., . . . Volek, J. (2003). Creatine supplementation increases total body water without altering fluid distribution. Journal of Athletic Training, 38(1), 44-50. PubMed

Powers, S.K., Nelson, W.B., \& Larson-Meyer, E. (2011). Antioxidant and Vitamin D supplements for athletes:sense or nonsense? Journal of Sports Sciences, 29(Suppl.1), S47-S55. doi:10.1080/02640414.2011. 602098

Prasad, A.S. (2014). Zinc is an antioxidant and anti-inflammatory agent: Its role in human health. Frontiers in Nutrition, 1, 14. doi:10.3389/fnut. 2014.00014

Rae, C.D., \& Broer, S. (2015). Creatine as a booster for human brain function. How might it work? Neurochemistry International, 89, 249-259. doi:10.1016/j.neuint.2015.08.010

Rawson, E.S., Clarkson, P.M., \& Tarnopolsky, M.A. (2017). Perspectives on Exertional Rhabdomyolysis. Sports Medicine, 47(Suppl.1), 33-49. doi:10.1007/s40279-017-0689-z

Rawson, E.S., Miles, M.P., \& Larson-Meyer, D.E. (2018). Dietary supplements for health, adaptation, and recovery in athletes. International Journal of Sport Nutrition and Exercise Metabolism, 28(2). doi:10. 1123/ijsnem.2017-0340

Rawson, E.S., \& Persky, A.M. (2007). Mechanisms of muscular adaptations to creatine supplementation: Review article. International SportMed Journal, 8(2), 43-53.

Rawson, E.S., \& Venezia, A.C. (2011). Use of creatine in the elderly and evidence for effects on cognitive function in young and old. Amino Acids, 40(5), 1349-1362. PubMed

Rawson, E.S., \& Volek, J.S. (2003). Effects of creatine supplementation and resistance training on muscle strength and weightlifting performance. Journal of Strength \& Conditioning Research, 17(4), 822831.

Requena, B., Zabala, M., Padial, P., \& Feriche, B. (2005). Sodium bicarbonate and sodium citrate: Ergogenic aids? Journal of Strength \& Conditioning Research, 19(1), 213-224. doi:10.1519/ 13733.1

Reynolds, C., Halpenny, C., Hughes, C., Jordan, S., Quinn, A., \& Egan, B. (2016). Acute ingestion of beetroot juice does not improve repeated sprint performance in male team sport athletes. Proceedings of the Nutrition Society, 75(OCE3), E97. doi:10.1017/S0029665116001129

Ribeiro, I.F., Miranda-Vilela, A.L., Klautau-Guimaraes Mde, N., \& Grisolia, C.K. (2013). The influence of erythropoietin (EPO T $\rightarrow \mathrm{G}$ ) and alpha-actinin-3 (ACTN3 R577X) polymorphisms on runners' responses to the dietary ingestion of antioxidant supplementation based on pequi oil (Caryocar brasiliense Camb.): A before-after study. Journal of Nutrigenetics and Nutrigenomics, 6(6), 283-304. doi:10.1159/000357947

Roberts, L., Bailes, J., Dedhia, H., Zikos, A., Singh, A., McDowell, D., . . . Carpenter, J. (2008). Surviving a mine explosion. Journal of the American College of Surgeons, 207(2), 276-283. doi:10.1016/ j.jamcollsurg.2008.02.015

Rowlands, D.S., \& Thomson, J.S. (2009). Effects of beta-hydroxy-betamethylbutyrate supplementation during resistance training on strength, body composition, and muscle damage in trained and untrained young men: A meta-analysis. Journal of Strength \& Conditioning Research, 23(3), 836-846.

Ruohola, J.P., Laaksi, I., Ylikomi, T., Haataja, R., Mattila, V.M., Sahi, T., ... Pihlajamaki, H. (2006). Association between serum 25(OH)D 
concentrations and bone stress fractures in Finnish young men. Journal of Bone and Mineral Research, 21(9), 1483-1488. doi:10. 1359/jbmr.060607

Sakellaris, G., Kotsiou, M., Tamiolaki, M., Kalostos, G., Tsapaki, E., Spanaki, M., . . . Evangeliou, A. (2006). Prevention of complications related to traumatic brain injury in children and adolescents with creatine administration: An open label randomized pilot study. The Journal of Trauma, 61(2), 322-329. doi:10.1097/01.ta.0000230269. 46108.d5

Sakellaris, G., Nasis, G., Kotsiou, M., Tamiolaki, M., Charissis, G., \& Evangeliou, A. (2008). Prevention of traumatic headache, dizziness and fatigue with creatine administration. A pilot study. Acta Paediatrica, 97(1), 31-34. PubMed doi:10.1111/j.1651-2227.2007. 00529.x

Saunders, B., Elliott-Sale, K., Artioli, G.G., Swinton, P.A., Dolan, E., Roschel, H., ... Gualano, B. (2016). Beta-alanine supplementation to improve exercise capacity and performance: A systematic review and meta-analysis. British Journal of Sports Medicine. doi:10.1136/ bjsports-2016-096396

Schilling, B.K., Stone, M.H., Utter, A., Kearney, J.T., Johnson, M., Coglianese, R., . . . Stone, M.E. (2001). Creatine supplementation and health variables: A retrospective study. Medicine \& Science in Sports \& Exercise, 33(2), 183-188.

Schneiker, K.T., Bishop, D., Dawson, B., \& Hackett, L.P. (2006). Effects of caffeine on prolonged intermittent-sprint ability in team-sport athletes. Medicine \& Science in Sports \& Exercise, 38(3), 578585. doi:10.1249/01.mss.0000188449.18968.62

Schrier, S.L., \& Auerbach, M. (2017). Treatment of iron deficiency anemia in adults. Retrieved from https://www.uptodate.com/contents/ treatment-of-iron-deficiency-anemia-in-adults

Sciberras, J.N., Galloway, S.D., Fenech, A., Grech, G., Farrugia, C., Duca, D., \& Mifsud, J. (2015). The effect of turmeric (Curcumin) supplementation on cytokine and inflammatory marker responses following 2 hours of endurance cycling. Journal of the International Society of Sports Nutrition, 12(1), 5. doi:10.1186/s12970-014-0066-3

Shaw, G., Lee-Barthel, A., Ross, M.L., Wang, B., \& Baar, K. (2017). Vitamin C-enriched gelatin supplementation before intermittent activity augments collagen synthesis. The American Journal of Clinical Nutrition, 105(1), 136-143. doi:10.3945/ajcn.116.138594

Siegler, J.C., Marshall, P.W.M., Bray, J., \& Towlson, C. (2012). Sodium bicarbonate supplementation and ingestion timing: Does it matter? Journal of Strength \& Conditioning Research, 26, 1953-1958. doi:10. 1519/JSC.0b013e3182392960

Singh, M., \& Das, R.R. (2013). Zinc for the common cold. The Cochrane Database of Systematic Reviews, (6), CD001364. doi:10.1002/ 14651858.CD001364.pub4

Smith, G.I., Atherton, P., Reeds, D.N., Mohammed, B.S., Rankin, D., Rennie, M.J., \& Mittendorfer, B. (2011a). Dietary omega-3 fatty acid supplementation increases the rate of muscle protein synthesis in older adults: A randomized controlled trial. The American Journal of Clinical Nutrition, 93(2), 402-412. doi:10.3945/ajcn.110.005611

Smith, G.I., Atherton, P., Reeds, D.N., Mohammed, B.S., Rankin, D., Rennie, M.J., \& Mittendorfer, B. (2011b). Omega-3 polyunsaturated fatty acids augment the muscle protein anabolic response to hyperinsulinaemia-hyperaminoacidaemia in healthy young and middle-aged men and women. Clinical Science (Lond), 121(6), 267-278.

Solimini, R., Rotolo, M.C., Mastrobattista, L., Mortali, C., Minutillo, A., Pichini, S., . . . Palmi, I. (2017). Hepatotoxicity associated with illicit use of anabolic androgenic steroids in doping. European Review for Medical and Pharmacological Sciences, 21(Suppl. 1), 7-16. PubMed
Solomons, N.W. (1998). Mild human zinc deficiency produces an imbalance between cell-mediated and humoral immunity. Nutrition Reviews, 56(1 Pt 1), 27-28.

Spriet, L.L. (2014). Exercise and sport performance with low doses of caffeine. Sports Medicine, 44(Suppl. 2), S175-S184. doi:10.1007/ s40279-014-0257-8

Steenge, G.R., Simpson, E.J., \& Greenhaff, P.L. (2000). Protein- and carbohydrate-induced augmentation of whole body creatine retention in humans. Journal of Applied Physiology (1985), 89(3), 1165-1171.

Stellingwerff, T., \& Cox, G.R. (2014). Systematic review: Carbohydrate supplementation on exercise performance or capacity of varying durations. Applied Physiology, Nutrition, and Metabolism, 39(9), 998-1011. doi:10.1139/apnm-2014-0027

Sullivan, P.G., Geiger, J.D., Mattson, M.P., \& Scheff, S.W. (2000). Dietary supplement creatine protects against traumatic brain injury. Annals of Neurology, 48(5), 723-729. PubMed

Szczesniak, K.A., Ostaszewski, P., Fuller, J.C., Jr., Ciecierska, A., \& Sadkowski, T. (2015). Dietary supplementation of beta-hydroxy-betamethylbutyrate in animals - a review. Journal of Animal Physiology and Animal Nutrition (Berl), 99(3), 405-417. doi:10.1111/jpn.12234

Talanian, J.L., \& Spriet, L.L. (2016). Low and moderate doses of caffeine late in exercise improve performance in trained cyclists. Applied Physiology, Nutrition, and Metabolism, 41(8), 850-855. doi:10. 1139/apnm-2016-0053

Thomas, D.T., Erdman, K.A., \& Burke, L.M. (2016). American College of Sports Medicine Joint Position Statement. Nutrition and Athletic Performance. Medicine \& Science in Sports \& Exercise, 48(3), 543-568. doi:10.1249/MSS.0000000000000852

Thompson, C., Vanhatalo, A., Jell, H., Fulford, J., Carter, J., Nyman, L., . . . Jones, A.M. (2016). Dietary nitrate supplementation improves sprint and high-intensity intermittent running performance. Nitric Oxide, 61, 55-61. PubMed doi:10.1016/j.niox.2016.10.006

Thompson, C., Wylie, L.J., Fulford, J., Kelly, J., Black, M.I., McDonagh, S.T., . . Jones, A.M. (2015). Dietary nitrate improves sprint performance and cognitive function during prolonged intermittent exercise. European Journal of Applied Physiology, 115(9), 1825-1834. doi:10.1007/s00421-015-3166-0

Tian, H., Guo, X., Wang, X., He, Z., Sun, R., Ge, S., \& Zhang, Z. (2013). Chromium picolinate supplementation for overweight or obese adults. The Cochrane Database of Systematic Reviews, (11), CD010063. doi:10.1002/14651858.CD010063.pub2

Tipton, K.D. (2015). Nutritional support for exercise-induced injuries. Sports Medicine, 45(Suppl. 1), S93-S104. doi:10.1007/s40279-0150398-4

Volek, J.S., \& Rawson, E.S. (2004). Scientific basis and practical aspects of creatine supplementation for athletes. Nutrition, 20(7-8), 609-614. PubMed doi:10.1016/j.nut.2004.04.014

Volman, J.J., Ramakers, J.D., \& Plat, J. (2008). Dietary modulation of immune function by beta-glucans. Physiology \& Behavior, 94(2), 276-284. doi:10.1016/j.physbeh.2007.11.045

Walker, G.J., Finlay, O., Griffiths, H., Sylvester, J., Williams, M., \& Bishop, N.C. (2007). Immunoendocrine response to cycling following ingestion of caffeine and carbohydrate. Medicine \& Science in Sports \& Exercise, 39(9), 1554-1560. doi:10.1249/mss. 0b013e3180a74228

Walsh, N.P., Blannin, A.K., Robson, P.J., \& Gleeson, M. (1998). Glutamine, exercise and immune function. Links and possible mechanisms. Sports Medicine, 26(3), 177-191. PubMed

Walsh, N.P., Gleeson, M., Shephard, R.J., Gleeson, M., Woods, J.A., Bishop, N.C., . . . Simon, P. (2011). Position statement. Part one: Immune function and exercise. Exercise Immunology Review, 17, 6-63. 
Watson, P., Judkins, C., Houghton, E., Russell, C., \& Maughan, R.J. (2009). Urinary nandrolone metabolite detection after ingestion of a nandrolone precursor. Medicine \& Science in Sports \& Exercise, 41(4), 766-772. doi:10.1249/MSS.0b013e31818edaeb

Wellington, B.M., Leveritt, M.D., \& Kelly, V.G. (2017). The effect of caffeine on repeat high intensity effort performance in rugby league players. International Journal of Sports Physiology and Performance, 12(2), 206-210. doi:10.1123/ijspp.2015-0689

Wiles, J.D., Coleman, D., Tegerdine, M., \& Swaine, I.L. (2006). The effects of caffeine ingestion on performance time, speed and power during a laboratory-based $1 \mathrm{~km}$ cycling time-trial. Journal of Sports Sciences, 24(11), 1165-1171. doi:10.1080/ 02640410500457687

Wilkinson, D.J., Hossain, T., Hill, D.S., Phillips, B.E., Crossland, H., Williams, J., . . . Atherton, P.J. (2013). Effects of leucine and its metabolite beta-hydroxy-beta-methylbutyrate on human skeletal muscle protein metabolism. The Journal of Physiology, 591(Pt 11), 2911-2923.

Wilson, J.M., Lowery, R.P., Joy, J.M., Andersen, J.C., Wilson, S.M., Stout, J.R., . . . Rathmacher, J. (2014). The effects of 12 weeks of beta-hydroxy-beta-methylbutyrate free acid supplementation on muscle mass, strength, and power in resistance-trained individuals: A randomized, double-blind, placebo-controlled study. European Journal of Applied Physiology, 114(6), 1217-1227.
Wilson, J.M., Lowery, R.P., Joy, J.M., Walters, J.A., Baier, S.M., Fuller, J.C., Jr., . . Rathmacher, J. (2013). Beta-Hydroxy-beta-methylbutyrate free acid reduces markers of exercise-induced muscle damage and improves recovery in resistance-trained men. The British Journal of Nutrition, 110(3), 538-544.

Wycherley, T.P., Moran, L.J., Clifton, P.M., Noakes, M., \& Brinkworth, G.D. (2012). Effects of energy-restricted high-protein, low-fat compared with standard-protein, low-fat diets: A meta-analysis of randomized controlled trials. The American Journal of Clinical Nutrition, 96(6), 1281-1298.

Wylie, L.J., Bailey, S.J., Kelly, J., Blackwell, J.R., Vanhatalo, A., \& Jones, A.M. (2016). Influence of beetroot juice supplementation on intermittent exercise performance. European Journal of Applied Physiology, 116(2), 415-425. doi:10.1007/s00421-015-3296-4

Wylie, L.J., Kelly, J., Bailey, S.J., Blackwell, J.R., Skiba, P.F., Winyard, P.G., . . Jones, A.M. (2013). Beetroot juice and exercise: Pharmacodynamic and dose-response relationships. Journal of Applied Physiology (1985), 115(3), 325-336. doi:10.1152/japplphysiol. 00372.2013

Zhang, Y.Y., Liu, W., Zhao, T.Y., \& Tian, H.M. (2017). Efficacy of omega-3 polyunsaturated fatty acids supplementation in managing overweight and obesity: A meta-analysis of randomized clinical trials. The Journal of Nutrition, Health \& Aging, 21(2), 187-192. doi: 10.1007/s12603-016-0755-5 